\title{
Immunogenicity of Biologics in Chronic Inflammatory Diseases: A Systematic Review
}

\author{
Vibeke Strand $^{1}{ }^{(1)} \cdot$ Alejandro Balsa $^{2} \cdot$ Jamal Al-Saleh $^{3} \cdot$ Leonor Barile-Fabris $^{4}$. \\ Takahiko Horiuchi $^{5}$ - Tsutomu Takeuchi ${ }^{6}$. Sadiq Lula $^{7} \cdot$ Charles Hawes $^{8}$. \\ Blerina Kola $^{8} \cdot$ Lisa Marshall $^{9}$
}

Published online: 13 June 2017

(C) The Author(s) 2017. This article is an open access publication

\begin{abstract}
Objectives A systematic review was conducted to explore the immunogenicity of biologic agents across inflammatory diseases and its potential impact on efficacy/safety.

Methods Literature searches were conducted through November 2016 to identify controlled and observational studies of biologics/biosimilars administered for treatment of rheumatoid arthritis (RA), psoriatic arthritis (PsA), juvenile idiopathic arthritis (JIA), ankylosing spondylitis
\end{abstract}

Electronic supplementary material The online version of this article (doi:10.1007/s40259-017-0231-8) contains supplementary material, which is available to authorized users.

Vibeke Strand

vibekestrand@me.com

1 Division of Immunology/Rheumatology, Stanford University School of Medicine, 306 Ramona Road, Portola Valley, CA 94028, USA

2 Rheumatology Unit, Instituto de Investigación Sanitaria del Hospital Universitario La Paz (IdiPAZ), Madrid, Spain

3 Rheumatology Section, Dubai Hospital, Dubai, United Arab Emirates

4 Hospital de Especialidades Centro Médico Nacional Siglo XXI, Instituto Mexicano del Seguro Social, México City, Mexico

5 Department of Internal Medicine, Kyushu University Beppu Hospital, Beppu, Japan

6 Division of Rheumatology, Department of Internal Medicine, Keio University School of Medicine, 35 Shinanomachi, Shinjuku-ku, Tokyo 160-8582, Japan

7 Market Access Solutions, Envision Pharma Group, London, UK

8 Pfizer Ltd, Surrey, UK

9 Medical Affairs, Pfizer, Collegeville, PA, USA
(AS), non-radiographic axial spondyloarthritis (nr-axSpA), psoriasis (Ps), Crohn's disease, and ulcerative colitis. Results Of $>21,000$ screened publications, 443 were included. Anti-drug antibody (ADAb) rates varied widely among biologics across diseases (and are not directly comparable because of immunoassay heterogeneity); the highest overall rates were reported with infliximab $(0-83 \%)$, adalimumab $(0-54 \%)$, and infliximab biosimilar CT-P13 (21-52\%), and the lowest with secukinumab $(0-1 \%)$, ustekinumab (1-11\%), etanercept $(0-13 \%)$, and golimumab (0-19\%). Most ADAbs were neutralizing, except those to abatacept and etanercept. ADAb+ versus $\mathrm{ADAb}$ - patients had lower rates of clinical response to adalimumab (RA, PsA, JIA, AS, Ps), golimumab (RA), infliximab (RA, PsA, AS, Ps), rituximab (RA), ustekinumab (Ps), and CT-P13 (RA, AS). Higher rates of infusion-related reactions were reported in infliximab- and CTP13-treated ADAb+ patients. Background immunosuppressives/anti-proliferatives reduced biologic immunogenicity across diseases.

Conclusions Based on reviewed reports, biologic/biosimilar immunogenicity differs among agents, with the highest rates observed with infliximab and adalimumab. As ADAb formation in biologic-/biosimilar-treated patients may increase the risk of lost response, the immunogenicity of these agents is an important (albeit not the only) consideration in the treatment decision-making process. 


\section{Key Points}

Across chronic inflammatory disease states, antidrug antibodies (ADAbs) were detected in as many as $50 \%$ of patients in studies of adalimumab, infliximab, and the infliximab biosimilar CT-P13, but in lower proportions of patients $(<20 \%)$ in studies of secukinumab, ustekinumab, etanercept, and golimumab. (Immunogenicity data are not directly comparable among studies because of heterogeneity in immunoassays and other methodological features.)

$\mathrm{ADAb}$ formation was associated with reduced clinical efficacy of several biologics/biosimilars, including adalimumab, golimumab, infliximab, rituximab, ustekinumab, and CT-P13, and higher risk of infusion reactions with infliximab and CT-P13.

Because of these potential clinical consequences, the immunogenicity of biologics/biosimilars is an essential (albeit not the only) consideration when clinicians select a therapeutic approach in patients with chronic immune-mediated inflammatory disease.

\section{Introduction}

Over the past few decades, the introduction and growing use of biologic agents has represented a major advance in the management of inflammatory diseases [1]. These biologic agents include a $\mathrm{T}$ cell activation inhibitor/co-stimulation modulator, tumor necrosis factor inhibitor (TNFi) monoclonal antibodies (mAbs) and receptor fusion protein, an anti-CD20 mAb, and anti-interleukin (IL)-17A, IL-6, IL-12/23 mAbs, which have unique protein structures and differing capacities to induce immune responses. Results from randomized controlled trials (RCTs) support the efficacy of biologics across a range of disease states, but a substantial proportion of patients fail to respond or have an inadequate response with initial treatment (primary failure), lose response over time (secondary failure), or develop potentially therapy-limiting adverse events (AEs). The presence of anti-drug antibodies (ADAbs) has been identified as an important (albeit not the only) contributor to treatment failure and increased risk of AEs in patients receiving biologic therapy [2-5]. Formation of immune complexes between ADAbs and biologics may increase clearance and reduce serum biologic levels and may have a more direct neutralizing effect on product target binding.
Measurement of the immunogenic potential of biologics is challenging, as ADAb detection is technically detailed and standardized criteria for assay sensitivity have not been established [2, 4], which explains in part published discrepancies in ADAbs reported for individual agents. Many factors may influence immunogenicity, including product-specific factors (e.g., protein structure), treatment-related factors (e.g., use of concomitant therapies, dosing, continuous or intermittent administration), and patient-related factors (e.g., genetic pre-disposition and underlying disease). Numerous studies of the immunogenicity of individual agents have been conducted, but immunoassay methodologies and study design features, including types [e.g., RCTs, longitudinal observational studies (LOSs)] and duration of treatment, vary widely and thus data interpretation is challenging [5]. Nonetheless, detailed and comprehensive reviews of the published literature on the immunogenicity of all marketed biologic agents across inflammatory disease states are needed to ensure that clinicians remain well informed on this critical issue.

We conducted a systematic literature review (SLR) to examine the immunogenicity of ten approved biologic agents and one approved biosimilar agent across inflammatory diseases. We particularly focused on the reported frequency of $\mathrm{ADAb}$ formation; potential effects of $\mathrm{ADAb}$ on pharmacokinetics, efficacy, safety, and treatment survival; and factors with a potential impact on the agent's immunogenic potential.

\section{Methods}

\subsection{Data Sources}

A comprehensive search strategy was developed to identify relevant RCTs and LOSs from the published literature. Searches of the following databases were conducted for studies published in English through November 2016: MEDLINE $^{\circledR}$, MEDLINE in Process and Other Non-Indexed Citations, Embase ${ }^{\circledR}$, Cochrane Central Register of Controlled Trials, and the Cochrane Database of Systematic Reviews. Manual searches were conducted of proceedings from the following conferences: the American College of Rheumatology; the European League Against Rheumatism; Advances in Inflammatory Bowel Disease, Crohn's and Colitis; the European Crohn's and Colitis Organisation; European Congress of Immunology; American Academy of Dermatology; European Academy of Dermatology and Venereology; and the International Congress on Spondyloarthropathies. Review articles/editorial reference lists, and previously conducted SLRs were also manually searched. A cross-referencing search was 
conducted post hoc to identify relevant studies not captured in the original searches because the incidence/prevalence of ADAbs was not included within the studies' abstracts. The cross-referencing search was conducted with an internet search engine (Google Scholar) using mAbspecific immunogenicity terms and manual review of the reference lists of new and existing published studies.

\subsection{Study Eligibility and Selection}

Eligible studies included RCTs, non-RCTs, and observational studies of patients treated for rheumatoid arthritis (RA), psoriatic arthritis (PsA), juvenile idiopathic arthritis (JIA), axial spondyloarthritis (axSpA), including ankylosing spondylitis (AS) and non-radiographic axSpA (nr$\operatorname{axSpA}$ ), psoriasis (Ps), and inflammatory bowel disease (IBD), including Crohn's disease (CD) and ulcerative colitis (UC). Studies of the following approved biologic and biosimilar agents were included: abatacept (ABA), adalimumab (ADA), certolizumab pegol (CZP), etanercept (ETN), golimumab (GLM), infliximab (INF), rituximab (RTX), secukinumab (SEC), tocilizumab (TCZ), ustekinumab (UST), and the INF biosimilar CT-P13 [Supplementary Table 1; see electronic supplementary material (ESM)].

In the first of two rounds of screening, titles and abstracts of publications identified in the literature searches were examined by a single reviewer for eligibility. A second validating reviewer conducted a quality check of $10 \%$ of the screened studies; if discrepancies were identified in $\geq 5 \%$ of the latter segment of screened studies, the screened studies were to be re-evaluated. Discrepancies were found in $0.6 \%$ of the studies. (Authors VS, AB, and SL reviewed all included studies for eligibility.) The complete texts of publications initially identified as eligible were subsequently examined in the second screening round, during which studies that failed to satisfy eligibility criteria were excluded. The validating reviewer inspected $20 \%$ of the publications excluded in this second screening and all publications eligible for inclusion. Discrepancies were resolved by a consensus among reviewers.

\subsection{Data Extraction}

The following categories of information were obtained from the selected studies: (i) publication details/study characteristics; (ii) population characteristics at baseline; and (iii) study outcomes (i.e., pharmacokinetics, safety, efficacy, and treatment survival) and variables assessed. A complete list of the extracted data is shown in Supplementary Table 2 (see ESM).

\subsection{Study Quality Assessment}

The quality of RCTs identified in the searches was assessed based on specifications from the National Institute for Health and Clinical Excellence single technology appraisal (STA) of manufacturers' submission of evidence [6] and the Jadad [7] scoring tools (Supplementary Table 3; see ESM). The checklist by Downs and Black [8] was used to appraise the quality or risk of bias of nonRCTs and LOSs in full publications (original checklist) and conference proceedings (modified checklist). Studies that received a poor rating on the risk of bias assessments were excluded.

\section{Results}

\subsection{Literature Search/Screening}

A total of 32,584 publications were initially identified in the literature; 27,560 were reviewed in the first screening, and 1148 in the second screening (Fig. 1). After 10 publications (10 studies) were excluded due to risk of bias (based on the Downs and Black checklist [8]) [9-18], 443 publications (394 studies) were included in the review. Due to the earlier introduction of ADA, ETN, and INF, these biologics had the greatest overall number of publications and studies included in the review (Supplementary Fig. 1; see ESM). The ratio of RCTs to non-RCTs and observational studies varied widely among the biologic/ biosimilar agents. A broad range of disease states, study durations, and immunoassay methods were found among the biologic/biosimilar studies (Tables 1,2). The timing of ADAb testing was often not reported; however, in most studies that provided this information, testing was conducted at study baseline and at multiple time points thereafter (frequently coinciding with visits scheduled for efficacy and safety assessment). Considerable variability is also seen in the demographic and disease characteristics at baseline of patients when assessed by individual diseases (studies, $n=293$; Supplementary Table 4; see ESM).

\subsection{Anti-Drug Antibody (ADAb) Formation}

The proportions of patients who developed treatment-induced ADAbs varied widely across biologic/biosimilar agents (Table 3). Data are represented as a range of ADAbs observed across studies and diseases included in the review. Comparisons of immunogenicity across agents should be conducted with caution due to fundamental differences in their molecular structure, number of studies reporting $\mathrm{ADAbs}$ for individual agents, disease states 
Fig. 1 Flow of publications/ studies through the search and screening process
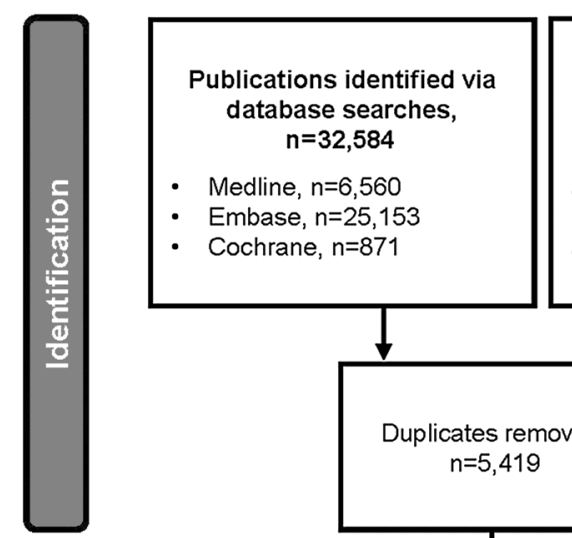

Additional publications identified via other sources, $\mathrm{n}=395$

- Reviews, references, and conferences, $n=179$

- Cross-referencing, $n=216$
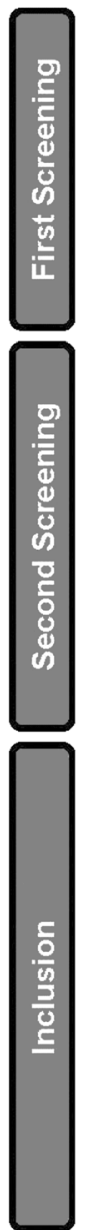

included, and study designs and assay methods. Agents associated with the highest overall rates of $\mathrm{ADAb}$ formation were INF (0-83\%), ADA (0-54\%), and the INF biosimilar CT-P13 (21-52\%), whereas those with the lowest were SEC (0-1\%), UST (1-11\%), ETN (0-13\%), and GLM (0-19\%). The incidence of ADA formation appeared to vary considerably across assay methods used and inflammatory disease states.

\subsection{Neutralizing and Non-Neutralizing ADAbs}

Neutralizing ADAbs have been reported with biologic/ biosimilar agents, including ADA [19, 20], CZP [21, 22], GLM [23-27], TCZ [28, 29], and CT-P13 [30, 31], albeit very infrequently with the fusion proteins ABA and ETN [2, 3, 32-34]. ADAbs against TNFi mAbs target idiotypes within or close to the epitope-binding 
Table 1 Summary of agents and disease states evaluated in included publications

\begin{tabular}{|c|c|c|c|c|c|c|c|c|}
\hline \multirow[t]{3}{*}{ Biologic/biosimilar } & \multicolumn{8}{|c|}{ No. of publications $\mathrm{s}^{\mathrm{a}}$} \\
\hline & \multicolumn{2}{|c|}{ No. of agents evaluated ${ }^{b}$} & \multicolumn{6}{|c|}{ Disease state } \\
\hline & Single & Multiple & RA & $\mathrm{AS}, \operatorname{axSpA}, \mathrm{SpA}$ & PsA & JIA & Ps & $\mathrm{CD}, \mathrm{UC}$ \\
\hline $\mathrm{ABA}(n=10)$ & 10 & 0 & 8 & 0 & 0 & 2 & 0 & 0 \\
\hline $\operatorname{ADA}(n=133)$ & 68 & 65 & 55 & 27 & 19 & 6 & 13 & 36 \\
\hline $\mathrm{CZP}(n=22)$ & 22 & 0 & 11 & 1 & 0 & 0 & 1 & 9 \\
\hline $\operatorname{ETN}(n=61)$ & 14 & 47 & 42 & 17 & 11 & 2 & 6 & 0 \\
\hline GLM $(n=36)$ & 34 & 2 & 21 & 7 & 2 & 0 & 0 & 7 \\
\hline $\mathrm{INF}(n=220)$ & 148 & 72 & 73 & 36 & 16 & 3 & 16 & 107 \\
\hline $\operatorname{RTX}(n=12)$ & 7 & 5 & 12 & 0 & 0 & 0 & 0 & 0 \\
\hline $\operatorname{SEC}(n=11)$ & 11 & 0 & 0 & 2 & 2 & 0 & 7 & 0 \\
\hline $\operatorname{TCZ}(n=22)$ & 22 & 0 & 19 & 0 & 0 & 3 & 0 & 0 \\
\hline UST $(n=15)$ & 14 & 1 & 0 & 0 & 2 & 0 & 11 & 2 \\
\hline CT-P13 $(n=13)$ & 2 & 11 & 7 & 4 & 1 & 0 & 1 & 4 \\
\hline
\end{tabular}

${ }^{a}$ Numbers represent all publications that report findings for the specified biologic/biosimilar and for the specified disease state

b Numbers of publications of studies in which a single biologic/biosimilar or multiple biologics/biosimilars were evaluated

$A B A$ abatacept, $A D A$ adalimumab, $A D A b$ anti-drug antibody, $A S$ ankylosing spondylitis, axSpA axial spondyloarthritis, CD Crohn's disease, CT-P13 INF biosimilar CT-P13, CZP certolizumab pegol, ETN etanercept, GLM golimumab, INF infliximab, JIA juvenile idiopathic arthritis, $P s$ psoriasis, $P s A$ psoriatic arthritis, $R A$ rheumatoid arthritis, $R T X$ rituximab, $S E C$ secukinumab, $S p A$ spondyloarthritis, $T C Z$ tocilizumab, UC ulcerative colitis, UST ustekinumab

\begin{tabular}{|c|c|c|c|c|c|c|c|c|}
\hline \multirow[t]{3}{*}{ Biologic/biosimilar } & \multicolumn{8}{|c|}{ Number of publications } \\
\hline & \multicolumn{3}{|c|}{ Study duration (week) } & \multicolumn{5}{|c|}{ Immunoassay method } \\
\hline & $\leq 24$ & $>24$ & NR & ELISA & ECL & RIA & Other & NR \\
\hline $\mathrm{ABA}(n=10)$ & 2 & 6 & 2 & 5 & 4 & & & 2 \\
\hline $\operatorname{ADA}(n=133)$ & 21 & 47 & 65 & 65 & & 28 & 13 & 27 \\
\hline $\mathrm{CZP}(n=22)$ & 8 & 12 & 2 & 13 & & 2 & & 7 \\
\hline $\operatorname{ETN}(n=61)$ & 11 & 26 & 24 & 34 & 1 & 10 & & 16 \\
\hline GLM $(n=36)$ & 9 & 24 & 3 & 26 & & 1 & & 9 \\
\hline $\mathrm{INF}(n=220)$ & 19 & 82 & 119 & 111 & 13 & 31 & 21 & 44 \\
\hline $\operatorname{RTX}(n=12)$ & 7 & 4 & 1 & 6 & 1 & & & 5 \\
\hline $\operatorname{SEC}(n=11)$ & 4 & 7 & & 3 & 3 & & 2 & 3 \\
\hline $\operatorname{TCZ}(n=22)$ & 4 & 14 & 4 & 13 & & & & 9 \\
\hline UST $(n=15)$ & & 12 & 3 & 7 & 1 & 1 & & 6 \\
\hline CT-P13 $(n=13)$ & & 12 & 1 & 3 & 9 & & & 1 \\
\hline
\end{tabular}

$A B A$ abatacept, $A D A$ adalimumab, $C T$-P13 INF biosimilar CT-P13, CZP certolizumab pegol, ECL electrochemiluminescent immunoassay, ELISA enzyme-linked immunosorbent assay, ETN etanercept, GLM golimumab, INF infliximab, $N R$ not reported, RIA radioimmunoassay, $R T X$ rituximab, SEC secukinumab, TCZ tocilizumab, UST ustekinumab portions in the Fab regions of the mAbs and prevent their binding to TNF $[35,36]$. Anti-idiotypic ADAbs are clinically important as they can directly diminish therapeutic activity by interfering with the agent's ability to execute its therapeutic mode of action. In addition, both neutralizing and non-neutralizing antibodies can impact clinical responses to biologics/biosimilars by forming immune complexes that may influence their pharmacokinetics (i.e., increased clearance) and lowering serum concentrations [35]. 
Table 3 Summary of ADAb formation rates for individual biologic/biosimilar by chronic inflammatory disease

\begin{tabular}{|c|c|c|c|c|c|c|c|c|}
\hline \multirow[t]{2}{*}{ Biologic } & \multicolumn{8}{|c|}{ Frequency of $\mathrm{ADAb}$ formation, $\%$ (no. of studies ${ }^{\mathrm{a}}$ ) } \\
\hline & RA & PsA & JIA & AS & Ps & $\mathrm{CD}$ & $\mathrm{UC}$ & Range \\
\hline $\mathrm{ABA}$ & $2-20(7)$ & & $2-11(2)$ & & & & & $2-20(9)$ \\
\hline ADA & $0-51(33)$ & $0-54(8)$ & $6-33(6)$ & 8-39 (9) & $0-51(12)$ & $0-35(13)$ & $3-5(3)$ & $0-54(80)$ \\
\hline $\mathrm{CZP}$ & $2.8-37(7)$ & & & & $21(1)$ & $3-25(6)$ & & $3-37(14)$ \\
\hline ETN & $0-13(25)$ & $0(3)$ & $0-6(2)$ & $0(4)$ & $2-5(5)$ & & & $0-13(37)$ \\
\hline GLM & $2-10(11)$ & $6(1)$ & & $0-6.4(2)$ & & & 0-19 (8) & $0-19$ (22) \\
\hline INF & $8-62(48)$ & $15-33(3)$ & $26-42(2)$ & $6.1-69(10)$ & $0-41$ (12) & $3-83$ (29) & $6-46(10)$ & $0-83(110)$ \\
\hline RTX & $0-21(8)$ & & & & & & & $0-21(8)$ \\
\hline SEC & & $0-0.1$ (3) & & $0-0.3(3)$ & $0-1(8)$ & & & $0-1(14)$ \\
\hline TCZ & $0-16$ (14) & & $1-8(3)$ & & & & & $0-16$ (17) \\
\hline UST & & $8-11$ (3) & & & $4-8.6(10)$ & $0-1(2)$ & & $1-11(15)$ \\
\hline CT-P13 & $26-52(2)$ & & & 27 (1) & & $21(1)$ & $24(1)$ & $21-52(5)$ \\
\hline
\end{tabular}

${ }^{a}$ Studies of patients with multiple chronic inflammatory diseases are included for each disease state

$A B A$ abatacept, $A D A$ adalimumab, $A D A b$ anti-drug antibody, $A S$ ankylosing spondylitis, $C D$ Crohn's disease, $C T$-P13 INF biosimilar CT-P13, $C Z P$ certolizumab pegol, ETN etanercept, GLM golimumab, INF infliximab, JIA juvenile idiopathic arthritis, $P s$ psoriasis, $P s A$ psoriatic arthritis, $R A$ rheumatoid arthritis, $R T X$ rituximab, SEC secukinumab, TCZ tocilizumab, UC ulcerative colitis, UST ustekinumab

\subsection{Impact of ADAbs}

\subsubsection{Pharmacokinetics}

In published studies of ADA [37-69], CZP [70-80], GLM [81], INF [1, 2, 36, 45, 46, 54, 57, 58, 60, 61, 63, 64, 67, 82-117], RTX [118], UST [119, 120], and CT-P13 [2, 30, $82-85,121,122]$, ADAb-positive patients were reported to have lower serum biologic concentrations than ADAbnegative patients. Differences in serum biologic concentrations between ADAb-positive and -negative patients were found to be statistically significant in studies of ADA [42-44, 47-50, 53-55, 57, 58, 61] and INF [54, 57, 58, 61, 87-91, 97, 98, 105, 107, 111, 113, 114] across chronic inflammatory diseases. In the Biologics in Rheumatoid Arthritis Genetics and Genomics Study Syndicate, a 12-month observational prospective cohort study, ADAbs against ADA were detected in 31 of 160 (19\%) ADAtreated patients and were significantly associated with lower ADA concentrations $\left(r_{\mathrm{s}}=-0.51 ; p<0.0001\right)$ [44]. In a prospective cohort study of PsA, Vogelzang et al. reported that 23 of $103(22 \%)$ patients had detectable ADAbs against ADA after 52 weeks and ADA concentrations were significantly lower after 28 and 52 weeks in ADAb-positive versus -negative patients (week 28: 1.3 vs $8.7 \mathrm{mg} / \mathrm{L}, p<0.001$; week 52: 0.9 vs $9.4 \mathrm{mg} / \mathrm{L}, p=0.0001$ ) [47, 48]. Significantly lower serum ADA concentrations have also been observed in patients with and without detectable ADAbs in prospective cohort studies of JIA [ADAb-positive, 6 of 23 (26\%), ADA serum concentrations, 1.6 vs $14.1 \mathrm{mg} / \mathrm{L}, p=0.006$ ] [49]; AS [31 of 115 (27\%), $1.2 \mathrm{vs} 12.7 \mathrm{mg} / \mathrm{L}, p<0.001$ ] [50]; Ps [27 of $53(51 \%), 0.8$ vs $4.8 \mathrm{mg} / \mathrm{L}, p<0.001$ ] [53]; and CD [5 of $23(22 \%), 7.5$ vs $9.5 \mathrm{mg} / \mathrm{L}, p=0.002]$ [55].

Similarly, in a prospective cohort study of INF in patients with rheumatic diseases (RA, axSpA, PsA, and others), ADAbs were detected in 12 of 24 (50\%) of patients, with significantly lower serum INF levels observed in patients who developed ADAbs versus those who did not $(0.004$ vs $3.8 \mathrm{mg} / \mathrm{L}, p=0.002)$ [58]. In a study of similar design conducted in patients with Ps, 6 of $20(30 \%)$ INF-treated patients developed ADAbs and serum INF levels were significantly lower in ADAb-positive patients $(1.2 \mathrm{vs} 4.1 \mu \mathrm{g} / \mathrm{L}, p<0.01)$ [54]. In the largest of several prospective cohort studies with significant and consistent findings in CD or UC, Levesque et al. found that 57 of $326(18 \%)$ patients had antibodies against INF and that a lower proportion of ADAb-positive patients had therapeutic INF concentrations compared with ADAbnegative patients after 8 weeks of treatment (14\% vs $76 \%$, $p<0.001$ ) [98].

\subsubsection{Clinical Efficacy}

A consistent association between development of ADAb positivity and efficacy has been reported in studies of several biologic/biosimilar agents (Supplementary Table 5; see ESM). Specifically, in RA, patients with ADAbs against ADA [19, 37-39, 41-44, 123-128], GLM [24, 81, 129], INF [2, 82-86, 90, 116, 124, 125, 128, 130-134], 
RTX [118, 135, 136], and CT-P13 [2, 82-85] showed less improvement in disease activity and were less likely to achieve clinical responses. Less robust evidence of such a relationship has been reported in studies of CZP [80] and ETN [137]. In ADA-treated patients with JIA, higher proportions of ADAb-positive patients experienced a loss of response than those without antibodies [49]. Similarly, responses were lower in $\mathrm{ADAb}$-positive patients receiving ADA and INF in studies of PsA [138-141], AS [58, 126, 142-145], and Ps [51-53, 146-149]; in patients receiving UST in Ps [120, 150]; and those receiving CTP13 in AS [30, 121, 122]. In several studies of CD and UC, clinical response/remission rates were found to be lower in patients with antibodies than in those without when treated with ADA [151], CZP [152], and INF [153-156].

\subsubsection{Safety/Tolerability}

The presence of ADAbs may also be associated with biologic/biosimilar safety and tolerability, with the most extensive evidence derived from studies of INF. In INF study publications, infusion-related reactions occurred in higher proportions of ADAb-positive versus -negative patients across several disease states, including RA [86, 90, 145, 157], JIA [158, 159], AS [144, 160, 161], Ps [162], and CD [154, 163-165], or UC [89, 111, 166, 167]. In a large retrospective cohort study conducted in patients with RA, Krintel et al. observed a significantly increased risk of discontinuation due to adverse drug reactions in patients who developed anti-INF antibodies compared with those who did not develop ADAbs after 6 weeks of treatment [hazard ratio (HR) 5.1; $p<0.0001$ ] and 14 weeks of treatment (HR 3.3; $p=0.0009$ ) [90]. In the PLANETRA (Programme evaLuating the Autoimmune disease iNvEstigational drug cT-p13 in RA) RCT, higher rates of infusion-related reactions were observed in ADAb-positive patients versus $\mathrm{ADAb}$-negative patients in groups receiving the biosimilar CT-P13 (87\% vs $8 \%$ ) and INF (81\% vs $10 \%)$ [83].

In a prospective cohort study in RA, AS, and PsA, AEs occurred more frequently in ADAb-positive patients than in ADAb-negative patients treated with ADA (27\% vs $15 \%$ ) [168]. In an RCT of ADA in patients with Ps, greater proportions of ADAb-positive versus -negative patients reportedly had infectious AEs (54\% vs 48\%), injection site reactions ( $23 \%$ vs $16 \%$ ), and hepatic-related AEs (39\% vs 30\%) [146]. Numerically higher rates of treatment-emergent AEs (89\% vs 68\%) and serious AEs ( $22 \%$ vs $16 \%$ ) were reported in patients with RA who developed anti-RTX ADAbs compared with those who did not [135, 136]. Studies of other biologics have not included findings on the effects of immunogenicity on safety/tolerability.

\subsubsection{Treatment Survival}

The relationship between treatment survival and immunogenicity of biologic/biosimilar agents has not been well studied, with little or no evidence available from study publications for most biologics. However, in RCTs of INF in patients with RA and/or axSpA, treatment survival times were found to be shorter in ADAb-positive patients [91, 131, 145]. Pascual-Salcedo et al. reported a significant difference in treatment survival (4.2 vs 8.9 years; $p=0.0006)$ in a cohort of RA patients with and without ADAbs against INF [131].

\subsection{Factors Associated with Immunogenicity}

\subsubsection{Structure/Target Molecule}

The protein structures of biologic/biosimilar agents, which are not identical to endogenous immunoglobulins, are capable of inducing immune responses and formation of ADAbs. Basic differences in the molecular structures of these agents (Fig. 2) may help explain differences in immunogenicity rates between agents. For example, rates of ADAb formation are higher with chimeric TNFi mAbs (e.g., INF) compared with some fully human TNFi mAbs (e.g., GLM) and fusion proteins (e.g., ETN) (Table 3). Interestingly, a marked difference has been reported in the immunogenic potential of GLM and ADA: GLM is fully humanized by homologous recombination with an immunogenicity rate of up to $10 \%$; ADA is developed by phage substitution, with ADAbs directed against the epitope binding region and an immunogenicity rate of up to $54 \%$. The receptor fusion proteins ABA and ETN both exhibit immunogenicity to the linker portion between soluble receptor and Fc portion, which may explain in part the low frequency of ADAb formation and lack of neutralizing activity.

The immunogenic potential of some biologic/biosimilar agents may also be related to the target molecule. For example, the low incidence of ADAbs observed with TCZ may be explained in part by the fact that IL-6 is necessary for the antibody response or that the assay sensitivity is low in the presence of circulating drug levels.

\subsubsection{Immune Complex Formation}

Formation of immune complexes between biologics/ biosimilars and the target protein may also be an important factor determining immunogenic potential [2]. The size of these immune complexes appears to vary by therapeutic agent, as the fusion protein ETN forms small complexes $(\leq 300 \mathrm{kDa})$, generally with only one of three trimers of $\mathrm{TNF} \alpha$, and monoclonal antibodies ADA and INF are able 


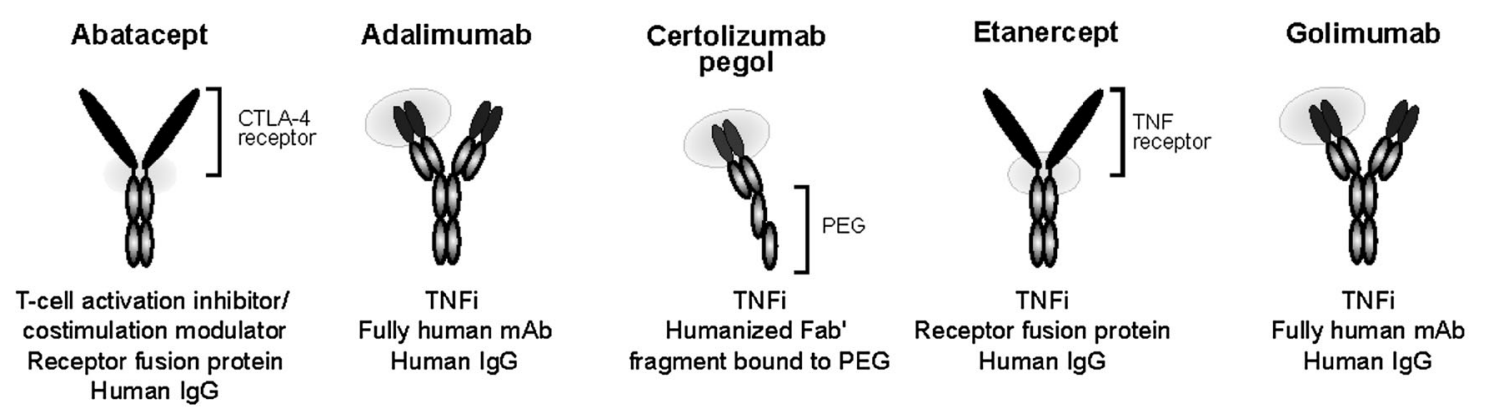

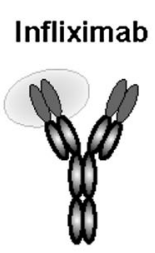

TNFi

Chimeric $\mathrm{mAb}$

Human IgG

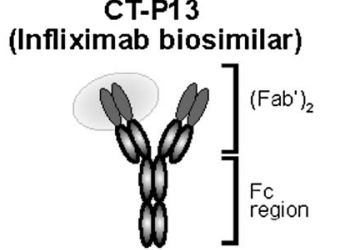

TNFi

Chimeric $\mathrm{mAb}$

Human IgG
Rituximab

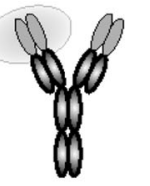

Anti-CD20

Chimeric mAb

Human lgG

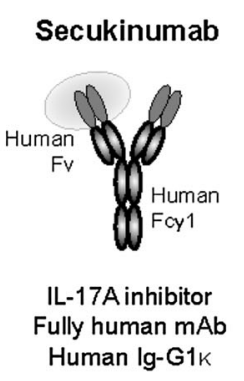

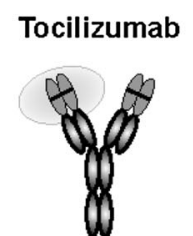

IL-6 inhibitor Humanized mAb Human IgG

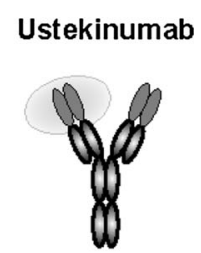

IL-12/23 inhibitor Fully human $\mathrm{mAb}$ Human IgG

Fig. 2 Immunogenic portions of molecular structures of biologic/biosimilar agents. $\operatorname{Ig} G$ immunoglobulin $\mathrm{G}, I L$ interleukin, $m A b$ monoclonal antibody, PEG polyethylene glycol, TNFi tumor necrosis factor- $\alpha$ inhibitor

to bind two trimers to form larger complexes $(\sim 4000 \mathrm{kDa}$ and $14,000 \mathrm{kDa}$, respectively) [101]. Large immune complexes are taken up earlier by antigen-presenting cells and are cleared from the system more rapidly, potentially resulting in greater immunogenicity [2].

\subsubsection{Background Therapy}

Evidence from many studies of biologic agents across disease states indicate that background immunosuppressive/anti-proliferative therapy reduces immunogenicity. As expected based on these agents' immunosuppressive mechanism, concomitant use of methotrexate, azathioprine, leflunomide, or mycophenolate is associated with lower rates of ADAbs against ADA in RA, JIA, AS, axSpA, and CD [38-40, 49, 143, 151, 169-173]; CZP in RA and CD [3, 62, 70-75, 78]; GLM in RA, PsA, AS, and UC [129, 174-182]; INF in RA, Ps, CD, and UC [91, 110, 111, 113, 114, 145, 153, 163, 165-167, 172, 183-195]; TCZ in RA [29]; and UST in PsA [119]. Differences in the benefit of methotrexate versus other immunosuppressives/anti-proliferatives in terms of immunogenicity were not evident from the literature.

\subsubsection{Biologic Dose/Regimen}

High biologic doses and induction therapy were also associated with decreased incidence of ADAbs in some published trials, including trials of ADA in RA and CD [37, 196-199]; CZP in RA and CD [70-75, 77]; INF in RA and CD [157, 163, 183, 186, 200]; and RTX in RA [201].
Patients who received continuous versus intermittent therapy with ADA, CZP, and INF were less likely to develop ADAbs [33, 53, 72-74, 202]. In addition, intravenous therapy is associated with less immunogenicity than subcutaneous administration of ABA [173] and GLM [174].

\subsubsection{Other}

Several reports in the literature also indicate that patients who previously developed ADAbs against a biologic agent are more likely to develop ADAbs with subsequent agents, although none are cross-reactive $[41,56,59,119$, 203-205]. Other factors, including sex, comorbid conditions, and ethnicity, may also influence immunogenicity but insufficient evidence was available for evaluation.

\section{Discussion}

In the RCTs and LOSs included in this review, ADAbs were detected in as many as one-half of patients treated with commonly used TNFi mAbs, and in a lower proportion of patients receiving other biologics. Across chronic inflammatory disease states, immunogenicity rates were highest $(>50 \%)$ in studies of ADA, INF, and the INF biosimilar CT-P13, and lowest $(<20 \%)$ in studies of SEC, GLM, ETN, and UST, but considerable variability in immunogenicity was seen between studies of the same and different agents. Differences between ADAb assays, including differences in assay interference by circulating serum biologic levels, and timing of ADAb testing, as well 
as differences in study design may have contributed to the observed fluctuations. The majority of older detection methods, such as enzyme-linked immunosorbent assays, are affected by 'drug interference'; as a result, ADAb levels may only be detected when they exceed biologic serum levels. Differences in sample collection timing and protocols between studies also can influence the results reported. Finally, other factors, such as study population characteristics, use of concomitant medications, and treatment modalities may also play a role. We noted that ADAb rates reported in the literature may differ from those reported in the agents' summary of product characteristics and product labeling, likely due to the use of different assays that are frequently proprietary and unpublished (Supplementary Table 6; see ESM).

The persistent presence of ADAbs decreases biologic activity via interference with epitope bindings and/or formation of immune complexes, which results in lower serum levels of the biologic and consequently possible loss of clinical response. Based on our literature search, we found the most extensive evidence of a link between ADAb formation and biologic pharmacokinetics in studies of the anti-TNF mAbs ADA and INF across several inflammatory diseases. Monitoring of ADAbs and biologic concentrations may provide essential information to clinicians that can potentially improve treatment management decisions as well as outcomes and reduce risks and costs. Interestingly, such assessment is not currently routine in rheumatology clinical practice, but heightened awareness of the immunogenic potential of biologics and the putative clinical consequences has been achieved among gastroenterologists who treat IBD [110, 206, 207]. Further research into immunogenicity, potential benefits of ADAb monitoring, and clinically validated, standardized ADAb assays are required to support this management approach in the future.

The impact of ADAbs against biologic/biosimilar agents on pharmacokinetics is just one consideration in their overall immunogenicity profile. The literature supports an association between $\mathrm{ADAb}$ formation and diminished clinical efficacy of several biologics/biosimilars, with the strongest evidence again reported in study publications of ADA and INF across disease states. Immunogenicity also has the potential to increase the frequency of AEs, particularly infusion site reactions with INF and the INF biosimilar CT-P13. Receptor fusion proteins ABA and ETN are not associated with neutralizing ADAbs, and little or no evidence is found in clinical studies of immunogenicity-related efficacy or safety/tolerability effects with these agents. It should be noted, however, that although no neutralizing activity was detected with the TNFi fusion protein lenercept, ADAbs were found to bind to the Fc portion of the molecule [208], occasionally resulting in serum sickness. The latter finding suggests that generalizations should be avoided with respect to immunogenicity potential, and biologics need to be characterized on a caseby-case basis. Use of background therapy, high biologic doses and/or induction regimens, and continuous versus intermittent treatment have been shown to reduce ADAb formation with biologics. Importantly, previous detection of ADAbs also appears to be associated with a higher incidence of immunogenicity with subsequently administered biologics.

Several limitations should be considered when evaluating the findings of this SLR. The review is only as informative as the reports published in the literature. More robust data are available for agents that have been marketed for longer periods; less data have been published for newer agents. The diversity of study type and design, patient populations, sample size and detection methods pose a major challenge in formulating conclusions based on this review. In particular, assay standardization and cross-laboratory validation is greatly needed. Findings may not reflect the true incidence of immunogenicity or the frequency/magnitude of its associated outcomes. When levels of the biologic/biosimilar exceed those of ADAbs, assays with drug interference underestimate the true prevalence of immunogenicity ('hidden immunogenicity'). Additional studies using a similar design and methodology are necessary to better define immunogenicity and associated outcomes. In addition, rates of $\mathrm{ADAb}$ formation reported in sponsored trials may differ substantially from those in real-world settings. Despite these acknowledged limitations, the majority of publications reported similar findings on the presence of ADAbs and their possible consequences in the chronic inflammatory diseases investigated.

\section{Conclusions}

In conclusion, based on data from reviewed reports, as many as $50 \%$ of patients receiving ADA, INF, and the INF biosimilar CT-P13 develop ADAbs. Factors such as the molecular structure, concomitant use of methotrexate or other immunosuppressive/anti-proliferative agents, dose and regimen of the biologic/biosimilar administered, history of ADAb development with previous biologic treatment, and patient sex, ethnicity, and comorbid conditions may influence the immunogenic potential of the agents. In the published literature, ADAb positivity has been consistently linked to diminished clinical improvement and loss of response with several biologic/biosimilar agents, including ADA, GLM, INF, RTX, and CT-P13, but direct causation has not been established and other processes may play a role. Although of less importance, some evidence 
suggests an elevated risk of hypersensitivity reactions in ADAb-positive patients, particularly with INF. Because of these potential clinical consequences, the immunogenicity of biologics/biosimilars is a vital (albeit not the only) consideration when selecting therapy, dose, and dosing regimen, and use of background immunosuppressive/antiproliferative agents in patients with chronic immune-mediated inflammatory disease.

Acknowledgements Medical writing support was provided by Donna McGuire of Engage Scientific Solutions and was funded by Pfizer. Carole Jones and Catherine Rolland, PhD, of Envision Pharma Group were involved with the development and conduct of the systematic literature review, which was funded by Pfizer.

\section{Compliance with Ethical Standards}

Funding The systematic literature review to support this manuscript was sponsored by Pfizer.

Conflict of interest Vibeke Strand has received consulting fees or honoraria for AbbVie, Alder, Amgen Corporation, Anthera, Asana, AstraZeneca, aTyr, Bayer, BiogenIdec, BMS, Boehringer Ingelheim, Carbylan, Celgene, Celltrion, CORRONA, Crescendo/Myriad Genetics, EMD Serono, Eupraxia, Genentech/Roche, GlaxoSmithKline, Horizon, Iroko, Janssen, Jazz Pharmaceuticals, Kezar, Kypha, Lilly, Merck, Novartis, Pfizer, Protagen, Regeneron, Samsung, Samumed, Sandoz, Sanofi, SKK, UCB, and XTL. Alejandro Balsa has received grants from AbbVie and Pfizer and consulting fees or honoraria from AbbVie, BMS, Janssen, MSD, Novartis, Pfizer, Roche, and UCB. Jamal Al-Saleh has received fees from Pfizer for a rheumatoid arthritis registry. Leonor Barile-Fabris and Takahiko Horiuchi reported no conflicts of interest. Tsutomu Takeuchi has received grants from AbbVie GK, Asahikasei Pharma Corp, Astellas Pharma, AYUMI Pharmaceutical Corporation, Bristol-Myers K.K., Chugai Pharmaceutical Co, Daiichi Sankyo, Eisai Co, Ltd, Janssen Pharmaceutical K.K., Mitsubishi Tanabe Pharma Corporation, Pfizer Japan Inc, Sanofi Aventis K.K., Santen Pharmaceutical Co, Ltd, SymBio Pharmaceuticals Ltd, Taisho Toyama Pharmaceutical Co, Takeda Pharmaceutical Company, and Teijin Pharma Limited; consultant fees or honoraria from AbbVie GK, Asahi Kasei Medical Co, Ltd, Astellas Pharma, AstraZeneca K.K., Bristol-Myers K.K., Daiichi Sankyo Co, Ltd, Eli Lilly Japan K.K., Janssen Pharmaceutical K.K., Merck Serono Co, Ltd, Nipponkayaku Co Ltd, Novartis Pharma K.K., Mitsubishi Tanabe Pharma Corporation, and Takeda Pharmaceutical Co, Ltd; and speaking fees from AbbVie GK, Astella Pharma, BristolMyers Squibb K.K., Celtrion, Chugai Pharmaceutical Co, Diaichi Sankyo Co, Ltd, Eisai Co, Ltd, Janssen Pharmaceutical K.K., Mitsubishi Tanabe Pharma Corporation, Nipponkayaku Co Ltd, Pfizer Japan Inc, and Takeda Pharmaceutical Company. During the development of the SLR and manuscript, Sadiq Lula was an employee of Envision Pharma Group, who were paid consultants to Pfizer in connection with the development of the systematic literature review report that forms the basis of this manuscript. He was not compensated for his role in the development of this manuscript. Charles Hawes, Blerina Kola, and Lisa Marshall are full-time employees and shareholders of Pfizer.

Open Access This article is distributed under the terms of the Creative Commons Attribution-NonCommercial 4.0 International License (http://creativecommons.org/licenses/by-nc/4.0/), which permits any noncommercial use, distribution, and reproduction in any medium, provided you give appropriate credit to the original author(s) and the source, provide a link to the Creative Commons license, and indicate if changes were made.

\section{References}

1. Strand V, Kimberly R, Isaacs JD. Biologic therapies in rheumatology: lessons learned, future directions. Nat Rev Drug Discov. 2007;6(1):75-92. doi:10.1038/nrd2196.

2. van Schouwenburg PA, Rispens T, Wolbink GJ. Immunogenicity of anti-TNF biologic therapies for rheumatoid arthritis. Nat Rev Rheumatol. 2013;9(3):164-72. doi:10.1038/nrrheum. 2013.4.

3. Jullien D, Prinz JC, Nestle FO. Immunogenicity of biotherapy used in psoriasis: the science behind the scenes. J Invest Dermatol. 2015;135(1):31-8. doi:10.1038/jid.2014.295.

4. Krieckaert C, Rispens T, Wolbink G. Immunogenicity of biological therapeutics: from assay to patient. Curr Opin Rheumatol. 2012;24(3):306-11. doi:10.1097/BOR.0b013e3283521c4e.

5. Garcês S, Demengeot J, Benito-Garcia E. The immunogenicity of anti-TNF therapy in immune-mediated inflammatory diseases: a systematic review of the literature with a meta-analysis. Ann Rheum Dis. 2013;72(12):1947-55. doi:10.1136/ annrheumdis-2012-202220.

6. National Institute for Health and Care Excellence. Specification for manufacturer/sponsor submission of evidence. Single technology appraisal (STA). 2012. http://www.ibrarian.net/navon/ paper/NATIONAL_INSTITUTE_FOR_HEALTH_AND_ CARE_EXCELLENCE.pdf?paperid=21998722. Accessed 26 May 2017.

7. Jadad AR, Moore RA, Carroll D, Jenkinson C, Reynolds DJ, Gavaghan DJ, et al. Assessing the quality of reports of randomized clinical trials: is blinding necessary? Control Clin Trial. 1996;17(1):1-12. http://www.ncbi.nlm.nih.gov/pubmed/ 8721797. Accessed 26 May 2017.

8. Downs SH, Black N. The feasibility of creating a checklist for the assessment of the methodological quality both of randomised and non-randomised studies of health care interventions. J Epidemiol Commun Health. 1998;52(6):377-84. http:// www.ncbi.nlm.nih.gov/pubmed/9764259. Accessed 26 May 2017.

9. Ruiz del Agua A, Pascual-Salcedo D, Balsa A, Ramos I, Novalbos L, Ramiro S, Martínez A, Simón L, Nagore D. Monitoring of anti-TNF biological treatments. J Transl Med. 2010;8(Suppl 1):P32. doi:10.1186/1479-5876-8-S1-P32.

10. Keystone EC, Kremer JM, Russell A, Box J, Abud-Mendoza C, Elizondo MG, et al. Abatacept in subjects who switch from intravenous to subcutaneous therapy: results from the phase IIIb ATTUNE study. Ann Rheum Dis. 2012;71(6):857-61. doi:10. 1136/annrheumdis-2011-200355.

11. Cozzani E, Burlando M, Parodi A. Detection of antibodies to anti-TNF agents in psoriatic patients: a preliminary study. G Ital Dermatol Venereol. 2013;148(2):171-4. http://www. minervamedica.it/en/journals/dermatologia-venereologia/article. php?cod=R23 Y2013N02A0171. Accessed 26 May 2017.

12. Malickova K, Duricova D, Bortlik M, Janatkova I, Zima T, Lukas M. Phosphatidylserine-dependent anti-prothrombin antibodies (aPS/PT) in infliximab-treated patients with inflammatory bowel diseases. Auto Immun Highlight. 2013;4(1):27-32. doi:10.1007/s13317-012-0045-0.

13. Szepes Z, Kunstár É, Farkas K, Nagy F, Gyulai R, Kui R, et al. Clinical utility of measuring serum TNF alpha level, anti TNF alpha levels and antibody titers in critical situations in 
inflammatory bowel disease and in psoriasis. J Crohn's Colitis. 2013;7:S118-9. doi:10.1016/S1873-9946(13)60295-0.

14. Velayos FS, Sheibani S, Lockton S, Hauenstein S, Singh S, Terdiman JP, et al. Prevalence of antibodies to adalimumab (ATA) and correlation between ATA and low serum drug concentration on CRP and clinical symptoms in a prospective sample of IBD patients. Gastroenterology. 2013;144(5):S91. http://www.gastrojournal.org/article/S0016-5085(13)60334-0/ pdf. Accessed 26 May 2017.

15. Verdet M, Guillou C, Golinski M-L, Hiron M, Jouen F, Boyer $O$, Lequerre $T$, Vittecoq $O$. Prolonging between-infusions interval is associated with positivity to anti-infliximab antibodies in rheumatoid arthritis and spondyloarthritis patients. Ann Rheum Dis. 2013;72:871. doi:10.1136/annrheumdis-2013-eular. 2600.

16. Wilson C, Huffman S, McGoogan K. Common factors among children who developed antibodies to infliximab. Inflamm Bowel Dis. 2013;19:S98. doi:10.1097/01.MIB.0000438922. 42887.80.

17. Leclerc M, Marotte H, Paul S, Del Tedesco E, Gonzalo P, Phelip $\mathrm{JM}$, et al. Persistence of antibodies to infliximab for more than two months strongly predicts loss of response to infliximab in inflammatory bowel diseases. J Crohn's Colitis. 2014;8:S1:S226-7. doi:10.1016/S1873-9946(14)60507-9.

18. Rosas J, Llinares-Tello F, Martín S, Senabre JM, Salas E, Oliver S, Santos Soler G, Santos Ramírez C, Barber X, Pons A, Cano $\mathrm{C}$, Lorente M. Evaluation of serum level of golimumab and antibodies anti-golimumab in patients with rheumatic diseases: results from a local registry. Ann Rheum Dis. 2014;73:935. doi:10.1136/annrheumdis-2014-eular.3862.

19. Bessette L, Khraishi M, Kivitz AJ, Kaliyaperumal A, Grantab R, Poulin-Costello M, et al. THU0143 Single-arm study of etanercept (ETN) in adult patients with moderate to severe rheumatoid arthritis (RA) who failed adalimumab (ADA) treatment. Ann Rheum Dis. 2016;75:233. http://ard.bmj.com/ content/75/Suppl_2/233.1. Accessed 26 May 2017.

20. Cohen SB, Genovese MC, Choy EH, Perez-Ruiz F, Pablos JL, Zhang N, et al. Randomized, double-blind, phase 3 study of efficacy and safety of ABP 501 compared with adalimumab in subjects with moderate to severe rheumatoid arthritis. Arthritis Rheum. 2015;67(Suppl 10):2054. http://acrabstracts.org/ abstract/randomized-double-blind-phase-3-study-of-efficacyand-safety-of-abp-501-compared-with-adalimumab-in-subjectswith-moderate-to-severe-rheumatoid-arthritis/. Accessed 26 May 2017.

21. Fleischmann R, Vencovsky J, van Vollenhoven RF, Borenstein D, Box J, Coteur G, et al. Efficacy and safety of certolizumab pegol monotherapy every 4 weeks in patients with rheumatoid arthritis failing previous disease-modifying antirheumatic therapy: the FAST4WARD study. Ann Rheum Dis. 2009;68(6):805-11. doi:10.1136/ard.2008.099291.

22. Smolen J, Landewe RB, Mease P, Brzezicki J, Mason D, Luijtens K, et al. Efficacy and safety of certolizumab pegol plus methotrexate in active rheumatoid arthritis: the RAPID 2 study. A randomised controlled trial. Ann Rheum Dis. 2009;68(6):797-804. doi:10.1136/ard.2008.101659.

23. Sandborn WJ, Feagan BG, Marano C, Zhang H, Strauss R, Johanns J, et al. Subcutaneous golimumab maintains clinical response in patients with moderate-to-severe ulcerative colitis. Gastroenterology. 2014;146(1):96-109 e1. doi:10.1053/j.gastro. 2013.06.010.

24. Weinblatt ME, Westhovens R, Mendelsohn AM, Kim L, Lo KH, Sheng $\mathrm{S}$, et al. Radiographic benefit and maintenance of clinical benefit with intravenous golimumab therapy in patients with active rheumatoid arthritis despite methotrexate therapy: results up to 1 year of the phase 3 , randomised, multicentre, double blind, placebo controlled GO-FURTHER trial. Ann Rheum Dis. 2014;73(12):2152-9. doi:10.1136/annrheumdis-2013-203742.

25. Bingham CO 3rd, Mendelsohn AM, Kim L, Xu Z, Leu J, Han C, et al. Maintenance of clinical and radiographic benefit with intravenous golimumab therapy in patients with active rheumatoid arthritis despite methotrexate therapy: week-112 efficacy and safety results of the open-label long-term extension of a phase III, double-blind, randomized placebo-controlled trial. Arthritis Care Res. 2015;67(12):1627-36. doi:10.1002/acr. 22556.

26. Smolen JS, Kay J, Doyle M, Landewe R, Matteson EL, Gaylis $\mathrm{N}$, et al. Golimumab in patients with active rheumatoid arthritis after treatment with tumor necrosis factor alpha inhibitors: findings with up to five years of treatment in the multicenter, randomized, double-blind, placebo-controlled, phase 3 GOAFTER study. Arthritis Res Ther. 2015;22(17):14. doi:10.1186/ s13075-015-0516-6.

27. Deodhar A, Braun J, Inman RD, van der Heijde D, Zhou Y, Xu $\mathrm{S}$, et al. Golimumab administered subcutaneously every 4 weeks in ankylosing spondylitis: 5-year results of the GO-RAISE study. Ann Rheum Dis. 2015;74(4):757-61. doi:10.1136/ annrheumdis-2014-205862.

28. Burmester GR, Rubbert-Roth A, Cantagrel A, Hall S, Leszczynski P, Feldman D, Rangaraj MJ, Roane G, Ludivico C, Lu P, Rowell L, Bao M, Mysler EF. A randomised, doubleblind, parallel-group study of the safety and efficacy of subcutaneous tocilizumab versus intravenous tocilizumab in combination with traditional disease-modifying antirheumatic drugs in patients with moderate to severe rheumatoid arthritis (SUMMACTA study). Ann Rheum Dis. 2014;73(1):69-74. doi:10. 1136/annrheumdis-2013-203523.

29. Dougados M, Kissel K, Conaghan PG, Mola EM, Schett G, Gerli R, et al. Clinical, radiographic and immunogenic effects after 1 year of tocilizumab-based treatment strategies in rheumatoid arthritis: the ACT-RAY study. Ann Rheum Dis. 2014;73(5):803-9. doi:10.1136/annrheumdis-2013-204761.

30. Park W, Yoo DH, Szanto S, Berghea F, Brzosko M, Wiland P, et al. Clinical response of disease activity, disability and mobility indices in relation to anti-drug antibody in the PLANETAS. Ann Rheum Dis. 2014;73:121. doi:10.1136/ annrheumdis-2014-eular.3804.

31. Takeuchi T, Yamanaka H, Tanaka Y, Sakurai T, Saito K, Ohtsubo $\mathrm{H}$, et al. Evaluation of the pharmacokinetic equivalence and 54-week efficacy and safety of CT-P13 and innovator infliximab in Japanese patients with rheumatoid arthritis. Mod Rheumatol. 2015;25(6):817-24. doi:10.3109/14397595.2015. 1022297.

32. Bendtzen K, Geborek P, Svenson M, Larsson L, Kapetanovic MC, Saxne T. Individualized monitoring of drug bioavailability and immunogenicity in rheumatoid arthritis patients treated with the tumor necrosis factor alpha inhibitor infliximab. Arthritis Rheum. 2006;54(12):3782-9. doi:10.1002/art.22214.

33. Vincent FB, Morand EF, Murphy K, Mackay F, Mariette X, Marcelli C. Antidrug antibodies (ADAb) to tumour necrosis factor (TNF)-specific neutralising agents in chronic inflammatory diseases: a real issue, a clinical perspective. Ann Rheum Dis. 2013;72(2):165-78. doi:10.1136/annrheumdis-2012-202545.

34. Bae SC, Kim J, Choe JY, Park W, Lee SH, Park YB, et al. A phase III, multicentre, randomised, double-blind, active-controlled, parallel-group trial comparing safety and efficacy of HD203, with innovator etanercept, in combination with methotrexate, in patients with rheumatoid arthritis: the HERA study. Ann Rheum Dis. 2017;76(1):65-71. doi:10.1136/ annrheumdis-2015-207613.

35. van Schouwenburg PA, van de Stadt LA, de Jong RN, van Buren EE, Kruithof S, de Groot E, et al. Adalimumab elicits a 
restricted anti-idiotypic antibody response in autoimmune patients resulting in functional neutralisation. Ann Rheum Dis. 2013;72(1):104-9. doi:10.1136/annrheumdis-2012-201445.

36. van Schie KA, Hart MH, de Groot ER, Kruithof S, Aarden LA, Wolbink GJ, et al. The antibody response against human and chimeric anti-TNF therapeutic antibodies primarily targets the TNF binding region. Ann Rheum Dis. 2015;74(1):311-4. doi:10. 1136/annrheumdis-2014-206237.

37. Miyasaka N. Clinical investigation in highly disease-affected rheumatoid arthritis patients in Japan with adalimumab applying standard and general evaluation: the CHANGE study. Mod Rheumatol. 2008;18(3):252-62. doi:10.1007/s10165-008-00450 .

38. Bartelds GM, Krieckaert CL, Nurmohamed MT, van Schouwenburg PA, Lems WF, Twisk JW, et al. Development of antidrug antibodies against adalimumab and association with disease activity and treatment failure during long-term followup. JAMA. 2011;305(14):1460-8. doi:10.1001/jama.2011.406.

39. Korswagen LA, Bartelds GM, Krieckaert CLM, Turkstra F, Nurmohamed MT, van Schaardenburg D, et al. Venous and arterial thromboembolic events in adalimumab-treated patients with antiadalimumab antibodies: a case series and cohort study. Arthritis Rheum. 2011;63(4):877-83. doi:10.1002/art.30209.

40. Krieckaert CL, Nurmohamed MT, Wolbink GJ. Methotrexate reduces immunogenicity in adalimumab treated rheumatoid arthritis patients in a dose dependent manner. Ann Rheum Dis. 2012;71(11):1914-5. doi:10.1136/annrheumdis-2012-201544.

41. van Schouwenburg PA, Krieckaert CL, Rispens T, Aarden L, Wolbink GJ, Wouters D. Long-term measurement of anti-adalimumab using $\mathrm{pH}$-shift-anti-idiotype antigen binding test shows predictive value and transient antibody formation. Ann Rheum Dis. 2013;72(10):1680-6. doi:10.1136/annrheumdis-2012202407.

42. Chen DY, Chen YM, Tsai WC, Tseng JC, Chen YH, Hsieh CW, et al. Significant associations of antidrug antibody levels with serum drug trough levels and therapeutic response of adalimumab and etanercept treatment in rheumatoid arthritis. Ann Rheum Dis. 2015;74(3):e16. doi:10.1136/annrheumdis-2013203893.

43. Jani M, Chinoy H, Warren RB, Fu B, Griffiths CE, Morgan AW, et al. Influence of immunogenicity and drug levels on the efficacy of long-term treatment of rheumatoid arthritis with adalimumab and etanercept: a UK-based prospective study. Ann Rheum Dis. 2014;73:608. doi:10.1136/annrheumdis-2014-eular. 3811.

44. Jani M, Chinoy H, Warren RB, Griffiths CE, Plant D, Fu B, et al. Clinical utility of random anti-tumor necrosis factor drug-level testing and measurement of antidrug antibodies on the long-term treatment response in rheumatoid arthritis. Arthritis Rheumatol. 2015;67(8):2011-9. doi:10.1002/art.39169.

45. Eng G, Omerovic E, Højsgaard P, Lindegaard HM, Jensen EK, Bouchelouche PN. Presence of antibodies to adalimumab and infliximab in patients with rheumatoid arthritis in clinical remission. Ann Rheum Dis. 2013;72:230. doi:10.1136/ annrheumdis-2013-eular.725.

46. Eng GP, Bendtzen K, Bliddal H, Stoltenberg M, Szkudlarek M, Fana $\mathrm{V}$, et al. Antibodies to infliximab and adalimumab in patients with rheumatoid arthritis in clinical remission: a crosssectional study. Arthritis. 2015;2015:784825. doi:10.1155/2015/ 784825.

47. Vogelzang E, Kneepkens E, Nurmohamed M, van Kuijk A, Rispens T, Wolbink G, et al. A diminished clinical response at 28 and 52 weeks of adalimumab treatment in patients with psoriatic arthritis is associated with anti-drug antibodies. Ann Rheum Dis. 2014;73:735-6. doi:10.1136/annrheumdis-2014eular.2162
48. Vogelzang EH, Kneepkens EL, Nurmohamed MT, van Kuijk AW, Rispens T, Wolbink G, et al. Anti-adalimumab antibodies and adalimumab concentrations in psoriatic arthritis; an association with disease activity at 28 and 52 weeks of follow-up. Ann Rheum Dis. 2014;73(12):2178-82. doi:10.1136/ annrheumdis-2014-205554.

49. Skrabl-Baumgartner A, Erwa W, Muntean W, Jahnel J. Antiadalimumab antibodies in juvenile idiopathic arthritis: frequent association with loss of response. Scand J Rheumatol. 2015;44(5):359-62. doi:10.3109/03009742.2015.1022213.

50. Kneepkens EL, Wei JC, Nurmohamed MT, Yeo KJ, Chen CY, van der Horst-Bruinsma IE, et al. Immunogenicity, adalimumab levels and clinical response in ankylosing spondylitis patients during 24 weeks of follow-up. Ann Rheum Dis. 2015;74(2):396-401. doi:10.1136/annrheumdis-2013-204185.

51. Lecluse LL, Driessen RJ, Spuls PI, de Jong EM, Stapel SO, van Doorn MB, et al. Extent and clinical consequences of antibody formation against adalimumab in patients with plaque psoriasis. Arch Dermatol. 2010;146(2):127-32. doi:10.1001/archdermatol. 2009.347.

52. Menting SP, van Lumig PP, de Vries AC, van den Reek JM, van der Kleij D, de Jong EM, et al. Extent and consequences of antibody formation against adalimumab in patients with psoriasis: one-year follow-up. JAMA Dermatol. 2014;150(2):130-6. doi:10.1001/jamadermatol.2013.8347.

53. Chiu HY, Wang TS, Chan CC, Lin SJ, Tsai TF. Risk factor analysis for the immunogenicity of adalimumab associated with decreased clinical response in Chinese patients with psoriasis. Acta Derm Venereol. 2015;95(6):711-6. doi:10.2340/ 00015555-2069.

54. Takahashi H, Tsuji H, Ishida-Yamamoto A, Iizuka H. Plasma trough levels of adalimumab and infliximab in terms of clinical efficacy during the treatment of psoriasis. J Dermatol Case Rep. 2013;40(1):39-42. doi:10.1111/j.1346-8138.2012.01679.x.

55. Bodini G, Savarino V, Dulbecco P, Baldissarro I, Savarino E. The influence of anti-adalimumab antibodies on adalimumab trough levels, TNF-alpha levels and clinical outcome. J Crohn's Colitis. 2014;8:S42. doi:10.1016/S1873-9946(14)60082-9.

56. Imaeda H, Takahashi K, Fujimoto T, Bamba S, Tsujikawa T, Sasaki M, et al. Clinical utility of newly developed immunoassays for serum concentrations of adalimumab and anti-adalimumab antibodies in patients with Crohn's disease. J Gastroenterol. 2014;49(1):100-9. doi:10.1007/s00535-0130803-4.

57. Kim HJ, Hwang J, Kim I, Jeong H, Lee J, Jeon CH, et al. Antidrug antibodies as a predictor for the discontinuation of antiTNF agents in patients with spondyloarthrtis. Ann Rheum Dis. 2014;73(Suppl 2):717-8. doi:10.1136/annrheumdis-2014-eular. 3465.

58. Mok CC, van der Kleij D, Wolbink GJ. Drug levels, anti-drug antibodies, and clinical efficacy of the anti-TNFalpha biologics in rheumatic diseases. Clin Rheumatol. 2013;32(10):1429-35. doi:10.1007/s10067-013-2336-x.

59. Yarur AJ, Deshpande AR, Sussman DA, Hauenstein S, Lockton $\mathrm{S}$, Barkin JS, et al. Serum adalimumab levels and antibodies correlate with endoscopic intestinal inflammation and inflammatory markers in patients with inflammatory bowel disease. Gastroenterology. 2013;144(5 (Suppl 1)):S-774-5. doi:10.1016/ S0016-5085(13)62863-2.

60. Yanai H, Lichtenstein L, Assa A, Mazor Y, Weiss B, Levine A, et al. Levels of drug and antidrug antibodies are associated with outcome of interventions after loss of response to infliximab or adalimumab. Clin Gastroenterol Hepatol. 2015;13(3):522-30.e2. doi:10.1016/j.cgh.2014.07.029.

61. Frederiksen MT, Ainsworth MA, Brynskov J, Thomsen O, Bendtzen K, Steenholdt C. Sa1236 Antibodies against 
infliximab are associated with increased risk of anti-adalimumab antibody development in patients with inflammatory bowel disease. Gastroenterology. 2014;146(5 Suppl 1):S-238. doi:10. 1016/S0016-5085(14)60840-4.

62. Zittan E, Kabakchiev B, Stempak JM, Nguyen GC, Croitoru K, van Assche G, et al. Tu1299 Higher adalimumab drug levels are associated with clinical and endoscopic remission in patients with Crohn's disease. Gastroenterol 2015;148(4 Suppl 1):S-852. doi:10.1016/S0016-5085(15)32887-0.

63. Ancuta C, Pomirleanu C, Belibou C, Maxim R, Petrariu L, Strugariu G, et al. THU0129 Clinical outcomes of immunogenicity in rheumatoid arthritis patients under anti-TNF biologics: results from an observational study. Ann Rheum Dis. 2016;75(Suppl 2):227. doi:10.1136/annrheumdis-2016-eular. 1886.

64. Ancuta C, Pomirleanu C, Belibou C, Maxim R, Petrariu L, Strugariu G, et al. SAT0385 Immunogenicity, Tnf-inhibitors levels and disease outcomes in ankylosing spondylitis: results from an observational cohort study. Ann Rheum Dis. 2016;75(Suppl 2):807. doi:10.1136/annrheumdis-2016-eular. 4271.

65. Baert F, Kondragunta V, Lockton S, Vande Casteele N, Hauenstein S, Singh S, et al. Antibodies to adalimumab are associated with future inflammation in Crohn's patients receiving maintenance adalimumab therapy: a post hoc analysis of the Karmiris trial. Gut. 2016;65(7):1126-31. doi:10.1136/gutjnl2014-307882.

66. Deaconu C, Opriş D, Mazilu D, Borangiu A, Groseanu L, Negru M, et al. A10.06 Detecting adalimumab serum level and antidrug antibodies-future tool in monitoring spondyloarthritis patients? Ann Rheum Dis. 2016;75(Suppl 1):A75. http://ard. bmj.com/content/75/Suppl_1/A75.1. Accessed 26 May 2017.

67. Eng GP, Bouchelouche P, Bartels EM, Bliddal H, Bendtzen K, Stoltenberg M. Anti-drug antibodies, drug levels, interleukin-6 and soluble TNF receptors in rheumatoid arthritis patients during the first 6 months of treatment with adalimumab or infliximab: a descriptive cohort study. PLoS One. 2016;11(9):e0162316. doi:10.1371/journal.pone.0162316.

68. Hammer HB, Bolstad N, Warren DJ, Goll GL, et al. FRI0114 Patients with low serum adalimumab concentrations display poor ultrasonographic response to treatment; results of a followup study of patients with rheumatoid arthritis. Ann Rheum Dis. 2015;74:461. http://ard.bmj.com/content/74/Suppl_2/461.1.info. Accessed 26 May 2017.

69. Yarur AJ, Jain A, Hauenstein SI, Quintero MA, Barkin JS, Deshpande AR, et al. Higher adalimumab levels are associated with histologic and endoscopic remission in patients with Crohn's disease and ulcerative colitis. Inflamm Bowel Dis. 2016;22(2):409-15. doi:10.1097/MIB.0000000000000689.

70. Takeuchi T, Yamamoto K, Yamanaka H, Ishiguro N, Tanaka Y, Eguchi K, et al. Immunogenicity of certolizumab pegol without concomitant methotrexate and clinical response in rheumatoid arthritis patients: post hoc analysis of the HIKARI study. Ann Rheum Dis. 2013;72:440. doi:10.1136/annrheumdis-2013-eular. 1328.

71. Takeuchi T, Yamamoto K, Yamanaka H, Ishiguro N, Tanaka Y, Eguchi K, et al. THU0190 Better clinical responses seen early with the loading dose of certolizumab pegol are maintained until one year. Ann Rheum Dis. 2014;73:247. doi:10.1136/ annrheumdis-2014-eular.1447.

72. Schreiber S, Khaliq-Kareemi M, Lawrance IC, Thomsen OO, Hanauer SB, McColm J, et al. Maintenance therapy with certolizumab pegol for Crohn's disease. $\mathrm{N}$ Engl J Med. 2007;357(3):239-50. doi:10.1056/NEJMoa062897.

73. Sandborn WJ, Feagan BG, Stoinov S, Honiball PJ, Rutgeerts P, Mason D, et al. Certolizumab pegol for the treatment of Crohn's disease. N Engl J Med. 2007;357(3):228-38. doi:10.1056/ NEJMoa067594.

74. Lichtenstein GR, Thomsen OO, Schreiber S, Lawrance IC, Hanauer SB, Bloomfield R, et al. Continuous therapy with certolizumab pegol maintains remission of patients with Crohn's disease for up to 18 months. Clin Gastroenterol Hepatol. 2010;8(7):600-9. doi:10.1016/j.cgh.2010.01.014.

75. Sandborn W, Binion D, Rubin D, Ullman T, Pierre-Louis B, Loftus E. Antibodies against certolizumab pegol (CZP), plasma concentrations of CZP and efficacy in patients with Crohn's disease receiving continuous CZP therapy with or without concomitant immunosuppressants. Am J Gastroenterol. 2011;106(Suppl 2) :S439-40. doi:10.1038/ajg.2011.336_9.

76. Schreiber S, Sandborn W, Choi J, Lee S, Wolf D, Abraham B, et al. P-100 Anti-drug antibodies separate responses of markers of inflammation (C-reactive protein, fecal calprotectin) in Crohn's disease patients treated with certolizumab pegol. Inflamm Bowel Dis. 2014;20:P100. doi:10.1097/01.MIB. 0000456839.99385.e2.

77. Sieper J, Landewe R, Rudwaleit M, van der Heijde D, Dougados $\mathrm{M}$, Mease PJ, et al. Effect of certolizumab pegol over ninety-six weeks in patients with axial spondyloarthritis: results from a phase III randomized trial. Arthritis Rheumatol. 2015;67(3):668-77. doi:10.1002/art.38973.

78. Lee SD, Rubin DT, Sandborn WJ, Randall C, Younes Z, Schreiber $S$, et al. Reinduction with certolizumab pegol in patients with Crohn's disease experiencing disease exacerbation: 7-Year Data from the PRECiSE 4 Study. Inflamm Bowel Dis. 2016;22(8):1870-80. doi:10.1097/MIB.0000000000000805.

79. Sandborn W, Dubinsky M, Kosutic G, et al. P-101 Incidence of anti-drug antibodies in Crohn's disease patients during 5 years of certolizumab pegol therapy. Inflamm Bowel Dis. 2016;22:S41. doi:10.1097/01.MIB.0000480206.37277.e8.

80. Takeuchi T, Yamamoto K, Yamanaka H, Ishiguro N, Tanaka Y, Eguchi K, et al. Post-hoc analysis showing better clinical response with the loading dose of certolizumab pegol in Japanese patients with active rheumatoid arthritis. Mod Rheumatol. 2016;26(4):473-80. doi:10.3109/14397595.2015.1109182.

81. Chen DY, Chen YM, Hung WT, Chen HH, Hsieh CW, Chen $\mathrm{YH}$, et al. Immunogenicity, drug trough levels and therapeutic response in patients with rheumatoid arthritis or ankylosing spondylitis after 24-week golimumab treatment. Ann Rheum Dis. 2015;74(12):2261-4. doi:10.1136/annrheumdis-2015207978 .

82. Yoo DH, Hrycaj P, Miranda P, Ramiterre E, Piotrowski M, Shevchuk $\mathrm{S}$, et al. A randomised, double-blind, parallel-group study to demonstrate equivalence in efficacy and safety of CTP13 compared with innovator infliximab when coadministered with methotrexate in patients with active rheumatoid arthritis: the PLANETRA study. Ann Rheum Dis. 2013;72(10):1613-20. doi:10.1136/annrheumdis-2012-203090.

83. Yoo DH, Racewicz A, Brzezicki J, Yatsyshyn R, Tobias Arteaga E, Baranauskaite A, et al. OP0068 A phase 3 randomised controlled trial to compare CT-P13 with infliximab in patients with active rheumatoid arthritis: 54 week results from the planetra study. Ann Rheum Dis. 2013;72:A73. doi:10.1136/ annrheumdis-2013-eular.273.

84. Yoo DH, Prodanovic N, Jaworski J, Miranda P, Ramiterre EB, Lanzon A, et al. Efficacy and safety of CT-P13 (infliximab biosimilar) over two years in patients with rheumatoid arthritis: comparison between continued CT-P13 and switching from infliximab to CT-P13. Arthritis Rheum. 2013;65(12):3319-3329. doi:10.1002/art.38257.

85. Yoo DH, Park W, Brzosko M, Géher P, Andersone D, Jaworski J, et al. THU0159 Disease activity assessment using the DAS28, CDAI and SDAI and effect of anti-drug antibody on clinical 
response in a randomized, double-blind, comparative trial of CT-P13 and innovator infliximab: planetra study. Ann Rheum Dis. 2014;73(Suppl 2):235.1. doi:10.1136/annrheumdis-2014eular.3707.

86. Okuyama A, Nagasawa H, Suzuki K, Kameda H, Kondo H, Amano K, et al. Fc $\gamma$ receptor IIIb polymorphism and use of glucocorticoids at baseline are associated with infusion reactions to infliximab in patients with rheumatoid arthritis. Ann Rheum Dis. 2011;70(2):299-304. doi:10.1136/ard.2010.136283.

87. van den Bemt BJ, den Broeder AA, Wolbink GJ, Hekster YA, van Riel PL, Benraad B, et al. Anti-infliximab antibodies are already detectable in most patients with rheumatoid arthritis halfway through an infusion cycle: an open-label pharmacokinetic cohort study. BMC Musculoskelet Disord. 2011;12:12. doi:10.1186/1471-2474-12-12.

88. Dervieux T, Weinblatt ME, Kivitz A, Kremer JM. Methotrexate polyglutamation in relation to infliximab pharmacokinetics in rheumatoid arthritis. Ann Rheum Dis. 2013;72(6):908-10. doi:10.1136/annrheumdis-2012-202591.

89. Warman A, Straathof JW, Derijks LJ. Therapeutic drug monitoring of infliximab in inflammatory bowel disease patients in a teaching hospital setting: results of a prospective cohort study. Eur J Gastroenterol Hepatol. 2015;27(3):242-8. doi:10.1097/ meg.0000000000000279.

90. Krintel SB, Grunert VP, Hetland ML, Johansen JS, Rothfuss M, Palermo G, et al. The frequency of anti-infliximab antibodies in patients with rheumatoid arthritis treated in routine care and the associations with adverse drug reactions and treatment failure. Rheumatology (Oxford). 2013;52(7):1245-53. doi:10.1093/ rheumatology/ket017.

91. Ducourau E, Mulleman D, Paintaud G, Miow Lin DC, Lauferon $\mathrm{F}$, Ternant $\mathrm{D}$, et al. Antibodies toward infliximab are associated with low infliximab concentration at treatment initiation and poor infliximab maintenance in rheumatic diseases. Arthritis Res Ther. 2011;13(3):R105. doi:10.1186/ar3386.

92. Steenholdt C, Brynskov J, Thomsen OO, Munck LK, Fallingborg J, Christensen LA, et al. Individualised therapy is more cost-effective than dose intensification in patients with Crohn's disease who lose response to anti-TNF treatment: a randomised, controlled trial. Gut. 2014;63(6):919-27. doi:10.1136/gutjnl2013-305279.

93. Steenholdt C, Brynskov J, Thomsen O, Munck LK, Fallingborg $\mathrm{J}$, Christensen LA, et al. Treatment of secondary infliximab failure in Crohn's disease based on serum levels of infliximab and antibodies against infliximab: the danish study of optimizing infliximab therapy in Crohn's disease (Do It Crohn) randomized clinical trial. Gastroenterology. 2013;144(5):S-22. doi:10.1016/ S0016-5085(13)60074-8

94. Steenholdt C, Bendtzen K, Brynskov J, Thomsen OO, Ainsworth MA. Clinical implications of measuring drug and antidrug antibodies by different assays when optimizing infliximab treatment failure in Crohn's disease: post hoc analysis of a randomized controlled trial. Am $\mathrm{J}$ Gastroenterol. 2014;109(7):1055-64. doi:10.1038/ajg.2014.106.

95. van Assche G, Magdelaine-Beuzelin C, D'Haens G, Baert F, Noman M, Vermeire S, et al. Withdrawal of immunosuppression in Crohn's disease treated with scheduled infliximab maintenance: a randomized trial. Gastroenterology. 2008;134(7):1861-8. doi:10.1053/j.gastro.2008.03.004.

96. Ben-Bassat O, Romanova A, Iacono A, Irwin SP, Greenberg GR. Association of serum infliximab and antibodies to infliximab to long-term clinical outcome and mucosal healing in Crohn's disease. Gastroenterology. 2013;144(5):S775. doi:10. 1016/S0016-5085(13)62866-8.

97. Imaeda H, Andoh A, Fujiyama Y. Development of a new immunoassay for the accurate determination of anti-infliximab antibodies in inflammatory bowel disease. J Gastroenterol. 2012;47(2):136-43. doi:10.1007/s00535-011-0474-y.

98. Levesque BG, Greenberg GR, Zou G, Sandborn WJ, Singh S, Hauenstein S, et al. A prospective cohort study to determine the relationship between serum infliximab concentration and efficacy in patients with luminal Crohn's disease. Aliment Pharmacol Ther. 2014;39(10):1126-35. doi:10.1111/apt.12733.

99. Vermeire S, Noman M, Van Assche G, Baert F, D'Haens G, Rutgeerts P. Effectiveness of concomitant immunosuppressive therapy in suppressing the formation of antibodies to infliximab in Crohn's disease. Gut. 2007;56(9):1226-31. doi:10.1136/gut. 2006.099978.

100. Ainsworth MA, Bendtzen K, Brynskov J. Tumor necrosis factoralpha binding capacity and anti-infliximab antibodies measured by fluid-phase radioimmunoassays as predictors of clinical efficacy of infliximab in Crohn's disease. Am J Gastroenterol. 2008;103(4):944-8. doi:10.1111/j.1572-0241.2007.01638.x.

101. Kohno T, Tam LT, Stevens SR, Louie JS. Binding characteristics of tumor necrosis factor receptor- $\mathrm{Fc}$ fusion proteins vs antitumor necrosis factor mAbs. J Investig Dermatol Symp Proc. 2007;12(1):5-8. doi:10.1038/sj.jidsymp.5650034.

102. Murthy S, Kevans D, Seow CH, Newman A, Steinhart AH, Silverberg MS, et al. Association of serum infliximab and antibodies to infliximab to long-term clinical outcome in acute ulcerative colitis. Gastroenterology. 2012;142(5 Suppl 1):S388. doi:10.1016/S0016-5085(12)61473-5.

103. Eser A, Primas C, Haunstein S, Lockton S, Wang S, Singh S, et al. P551 Detection of anti infliximab antibodies in patients with inflammatory bowel disease (IBD) in the presence of infliximab by homogeneous liquid phase anti infliximab mobility shift assay. J Crohn's Colitis. 2013;7(Suppl 1):S231-2. doi:10.1016/S1873-9946(13)60572-3.

104. Hämäläinen A, Sipponen T, Kolho KL. Serum infliximab concentrations in pediatric inflammatory bowel disease. Scand $\mathrm{J}$ Gastroenterol. 2013;48(1):35-41. doi:10.3109/00365521.2012. 741619.

105. Pallagi-Kunstár É, Farkas K, Szepes Z, Nagy F, Szucs M, Kui R, et al. Utility of serum TNF-alpha, infliximab trough level, and antibody titers in inflammatory bowel disease. World J Gastroenterol. 2014;20(17):5031-5. doi:10.3748/wjg.v20.i17.5031.

106. Paul S, Del Tedesco E, Marotte H, Rinaudo-Gaujous M, Moreau A, Phelip J-M, et al. Therapeutic drug monitoring of infliximab and mucosal healing in inflammatory bowel disease: a prospective study. Inflamm Bowel Dis. 2013;19(12):2568-76. doi:10.1097/MIB.0b013e3182a77b41.

107. Rivera Rivera ED, Liao C, Van't Hof K, Mangatu TA, Kahn SA, Gokhale RR, et al. Correlation between infliximab levels (IFX) and antibody to infliximab (ATI) in pediatric patients with inflammatory bowel disease (IBD) with the commercially available assay using electrochemilumescense. Gastroenterology. 2014;146(5):S782-3. doi:10.1016/S0016-5085(14)628237.

108. Ungar B, Chowers Y, Yavzori M, Picard O, Fudim E, Har-Noy $\mathrm{O}$, et al. The temporal evolution of antidrug antibodies in patients with inflammatory bowel disease treated with infliximab. Gut. 2014;63(8):1258-64. doi:10.1136/gutjnl-2013305259 .

109. Wolf DC, Lockton S, Hauenstein S, Carroll S, Singh S, Chuang E. Su1192 A multi-center observational study in community gastroenterology practices evaluating the clinical usage of testing for serum levels of infliximab and antibodies to infliximab. Gastroenterology. 2013;144(5 Suppl 1):S-423. doi:10.1016/ S0016-5085(13)61559-0.

110. Hendy P, Hart A, Irving P. Anti-TNF drug and antidrug antibody level monitoring in IBD: a practical guide. Frontline Gastroenterol. 2016;7(2):122-8. doi:10.1136/flgastro-2014-100527. 
111. Vande Casteele N, Gils A, Singh S, Ohrmund L, Hauenstein S, Rutgeerts $\mathrm{P}$, et al. Antibody response to infliximab and its impact on pharmacokinetics can be transient. Am J Gastroenterol. 2013;108(6):962-71. doi:10.1038/ajg.2013.12.

112. Yanai H, Lichtenstein L, Assa A, Mazor Y, Weiss B, Levine A, et al. Su1121 Anti-TNF and anti-drug antibodies levels predict the outcomes of interventions after loss of response to adalimumab and infliximab. Gastroenterology. 2014;146(5 Suppl 1):S-381. doi:10.1016/S0016-5085(14)61370-6.

113. Zitomersky NL, Atkinson BJ, Fournier K, Mitchell PD, Stern $\mathrm{JB}$, Butler MC, et al. Antibodies to infliximab are associated with lower infliximab levels and increased likelihood of surgery in pediatric IBD. Inflamm Bowel Dis. 2015;21(2):307-14. doi:10.1097/MIB.0000000000000284.

114. Guidi L, Marzo M, Tolusso B, Felice C, Andrisani G, Canestri $\mathrm{S}$, et al. Assay of infliximab trough levels and of total antibodies to infliximab in the management of loss of response. J Crohn's Colitis. 2015;9(Suppl 1):S322. doi:10.1093/ecco-jcc/jju027.604.

115. Hall B, Holleran G, Warnock Y, Bailey Y, Byrne S, Smith S, et al. Are human anti-human (HAHA) antibodies important in determining response to biologic therapies in inflammatory bowel disease? Ir J Med Sci. 2015;184(Suppl 3):67. https://link. springer.com/article/10.1007\%2Fs11845-014-1245-6. Accessed 26 May 2017.

116. Ishikawa Y, Fujii T, Ishikawa SK, Yukawa N, Hashimoto M, Furu $\mathrm{M}$, et al. Immunogenicity and lupus-like autoantibody production can be linked to each other along with type I interferon production in patients with rheumatoid arthritis treated with infliximab: a retrospective study of a single center cohort. PLoS One. 2016;11(9):e0162896. doi:10.1371/journal.pone.0162896.

117. Jurado T, Plasencia C, Martínez-Feito A, Navarro-Compan V, Olariaga E, Diego C, et al. Low levels of infliximab at early stages predict the loss of drug levels and the clinical response at one year of treatment in patients with rheumatoid arthritis. Ann Rheum Dis. 2016;75(Suppl 2):490. doi:10.1136/annrheumdis-2016-eular.3515.

118. Thurlings RM, Teng O, Vos K, Gerlag DM, Aarden L, Stapel $\mathrm{SO}$, et al. Clinical response, pharmacokinetics, development of human anti-chimaeric antibodies, and synovial tissue response to rituximab treatment in patients with rheumatoid arthritis. Ann Rheum Dis. 2010;69(2):409-12. doi:10.1136/ard.2009.109041.

119. Zhu Y, Keen M, Gunn G, Schantz A, Li S, Mendelsohn A, et al. Immunogenicity and clinical relevance of ustekinumab in two phase 3 studies in patients with active psoriatic arthritis. Clin Pharmacol Drug Dev. 2013;2:32. doi:10.1002/cpdd.62.

120. Chiu H-Y, Chu TW, Cheng Y-P, Tsai T-F. The association between clinical response to ustekinumab and immunogenicity to ustekinumab and prior adalimumab. PLoS One. 2015;10(11):e0142930. doi:10.1371/journal.pone.0142930.

121. Park W, Hrycaj P, Jeka S, Kovalenko V, Lysenko G, Miranda P, et al. A randomised, double-blind, multicentre, parallel-group, prospective study comparing the pharmacokinetics, safety, and efficacy of CT-P13 and innovator infliximab in patients with ankylosing spondylitis: the PLANETAS study. Ann Rheum Dis. 2013;72(10):1605-12. doi:10.1136/annrheumdis-2012-203091.

122. Park W, Miranda P, Brzosko M, Wiland P, Gutierrez-Urena S, Mikazane H, et al. Efficacy and safety of CT-P13 (infliximab biosimilar) over two years in patients with ankylosing spondylitis: comparison between continuing with CT-P13 and switching from infliximab to CT-P13. Arthritis Rheum. 2013;65(12):3326. http://onlinelibrary.wiley.com/doi/10.1002/ art.38257/pdf. Accessed 26 May 2017.

123. Krieckaert CL, Jamnitski A, Nurmohamed MT, Kostense PJ, Boers M, Wolbink G. Comparison of long-term clinical outcome with etanercept treatment and adalimumab treatment of rheumatoid arthritis with respect to immunogenicity. Arthritis Rheum. 2012;64(12):3850-5. doi:10.1002/art.34680.
124. Radstake TR, Svenson M, Eijsbouts AM, van den Hoogen FH, Enevold C, van Riel PL, et al. Formation of antibodies against infliximab and adalimumab strongly correlates with functional drug levels and clinical responses in rheumatoid arthritis. Ann Rheum Dis. 2009;68(11):1739-45. doi:10.1136/ard.2008.092833.

125. Garcês S, Antunes M, Benito-Garcia E, Da Silva JC, Aarden L, Demengeot J. A preliminary algorithm introducing immunogenicity assessment in the management of patients with RA receiving tumour necrosis factor inhibitor therapies. Ann Rheum Dis. 2014;73(6):1138-43. doi:10.1136/annrheumdis-2013-203296.

126. Jung SM, Kim H-S, Kim H-R, Kim NY, Lee J-H, Kim J, et al. Immunogenicity of anti-tumour necrosis factor therapy in Korean patients with rheumatoid arthritis and ankylosing spondylitis. Int Immunopharmacol. 2014;21(1):20-5. doi:10. 1016/j.intimp.2014.04.006.

127. Avdeeva AS, Aleksandrova EN, Novikov AA, Karateev DE, Luchihina EL, Cherkasova MV, et al. AB0370 Association of clinical efficacy with serum level of adalimumab (ADA) and anti-adalimumab antibody levels in patients with early rheumatoid arthritis (RA). Ann Rheum Dis. 2014;73(Suppl 2):927. doi:10.1136/annrheumdis-2014-eular.2266.

128. Villalba A, Plasencia C, Peiteado D, Nuño L, Bonilla G, Lojo L, et al. Influence of immunogenicity of anti-TNF therapy in RA patients with a long-term treatment with infliximab or adalimumab. Ann Rheum Dis. 2013;72(Suppl 3):A221. doi:10.1136/ annrheumdis-2013-eular.699.

129. Kremer J, Ritchlin C, Mendelsohn A, Baker D, Kim L, Xu Z, et al. Golimumab, a new human anti-tumor necrosis factor alpha antibody, administered intravenously in patients with active rheumatoid arthritis: forty-eight-week efficacy and safety results of a phase III randomized, double-blind, placebo-controlled study. Arthritis Rheum. 2010;62(4):917-28. doi:10.1002/art.27348.

130. Wolbink GJ, Vis M, Lems W, Voskuyl AE, de Groot E, Nurmohamed MT, et al. Development of antiinfliximab antibodies and relationship to clinical response in patients with rheumatoid arthritis. Arthritis Rheum. 2006;54(3):711-5. doi:10.1002/art. 21671.

131. Pascual-Salcedo D, Plasencia C, Ramiro S, Nuño L, Bonilla G, Nagore D, et al. Influence of immunogenicity on the efficacy of long-term treatment with infliximab in rheumatoid arthritis. Rheumatology (Oxford). 2011;50(8):1445-52. doi:10.1093/ rheumatology/ker124.

132. Lukina G, Sigidin Y, Alexandrova E, Novikov A, Aronova E. AB0463 Clinical significance of antibodies to infliximab in rheumatoid arthritis (RA) patients. Ann Rheum Dis. 2013;71(Suppl 3):664. doi:10.1136/annrheumdis-2012-eular.463.

133. Choe J-Y, Smolen JS, Keystone E, Genovese MC, Choi J, Rho YH. Efficacy and safety analysis by overall anti-drug antibody results up to week 30 in patients with rheumatoid arthritis treated with $\mathrm{Sb} 2$ (an infliximab biosimilar) or infliximab reference product in phase III study. Ann Rheum Dis. 2016;75(Suppl 2):232. doi:10.1136/annrheumdis-2016-eular.3359.

134. Valor L, Hernández-Flórez D, de la Torre I, del Rio T, Nieto JC, Gonzaléz C, et al. Investigating the link between disease activity and infliximab serum levels in rheumatoid arthritis patients. Clin Exp Rheumatol. 2015;33(6):805-11. http://www.clinexprheumatol.org/ abstract.asp?a=8964. Accessed 26 May 2017.

135. Yoo DH, Park W, Jeka S, Molina FC, Hrycaj P, Wiland P, et al. A randomized, controlled, multicenter, 2-arm, parallel-group, double-blind study to demonstrate the equivalence of CT-P10 to innovator rituximab with respect to pharmacokinetic profile in patients with rheumatoid arthritis. Arthritis Rheum. 2013;65(10 Suppl):1736. doi:10.1002/art.2013.65.issue-s10.

136. Yoo D-H, Park W, Jeka S, Molina FC, Hrycaj P, et al. Impact of anti-drug antibody on efficacy and safety over week 24 in both CT-P10 and innovator rituximab treatment groups. Arthritis 
Rheumatol. 2014;66(Suppl):S663-4. http://acrabstracts.org/ abstract/impact-of-anti-drug-antibody-on-efficacy-and-safetyover-week-24-in-both-ct-p10-and-innovator-rituximab-treatmentgroups/. Accessed 26 May 2017.

137. Emery P, Vencovsky J, Sylwestrzak A, Leszczynski P, Porawska W, Baranauskaite A, et al. A phase III randomised, double-blind, parallel-group study comparing SB4 with etanercept reference product in patients with active rheumatoid arthritis despite methotrexate therapy. Ann Rheum Dis. 2017;76(1):51-7. doi:10.1136/annrheumdis-2015-207588.

138. van Kuijk AW, de Groot M, Stapel SO, Dijkmans BA, Wolbink GJ, Tak PP. Relationship between the clinical response to adalimumab treatment and serum levels of adalimumab and anti-adalimumab antibodies in patients with psoriatic arthritis. Ann Rheum Dis. 2010;69(2):624-5. doi:10.1136/ard.2009. 108787.

139. Cajigas D, Plasencia C, Pascual-Salcedo D, Bonilla G, Alcocer $\mathrm{P}$, García-Carazo S, et al. The immunogenicity of biological therapies correlates with clinical efficacy in psoriatic arthritis (PsA) in long-term treatment with infliximab and adalimumab. Ann Rheum Dis. 2013;72:A964-5. doi:10.1136/annrheumdis2013-eular.2895.

140. Antoni C, Krueger GG, de Vlam K, Birbara C, Beutler A, Guzzo $\mathrm{C}$, et al. Infliximab improves signs and symptoms of psoriatic arthritis: results of the IMPACT 2 trial. Ann Rheum Dis. 2005;64(8):1150-7. doi:10.1136/ard.2004.032268.

141. Kavanaugh A, Krueger GG, Beutler A, Guzzo C, Zhou B, Dooley LT, et al. Infliximab maintains a high degree of clinical response in patients with active psoriatic arthritis through 1 year of treatment: results from the IMPACT 2 trial. Ann Rheum Dis. 2007;66(4):498-505. doi:10.1136/ard.2006.058339.

142. de Vries MK, Brouwer E, van der Horst-Bruinsma IE, Spoorenberg A, van Denderen JC, Jamnitski A, et al. Decreased clinical response to adalimumab in ankylosing spondylitis is associated with antibody formation. Ann Rheum Dis. 2009;68(11):1787-8. doi:10.1136/ard.2009.109702.

143. Davis J, Peng JZ, Noertersheuser PA, Paulson S, Van der Heijde D, Schiff D. Pharmacokinetics of adalimumab in patients with active ankylosing spondylitis (AS)—-the Atlas trial. Ann Rheum Dis. 2006;65(Suppl II):537. http://www.abstracts2view.com/ eular/view.php?nu=EULAR06L_2006SAT0285\&terms=. Accessed 26 May 2017.

144. de Vries MK, Wolbink GJ, Stapel SO, de Vrieze H, van Denderen JC, Dijkmans BA, et al. Decreased clinical response to infliximab in ankylosing spondylitis is correlated with anti-infliximab formation. Ann Rheum Dis. 2007;66(9):1252-4. doi:10.1136/ard.2007.072397.

145. Plasencia C, Pascual-Salcedo D, Nuño L, Bonilla G, Villalba A, Peiteado $\mathrm{D}$, et al. Influence of immunogenicity on the efficacy of longterm treatment of spondyloarthritis with infliximab. Ann Rheum Dis. 2012;71(12):1955-60. doi:10.1136/annrheumdis2011-200828.

146. Asahina A, Nakagawa H, Etoh T, Ohtsuki M. Adalimumab in Japanese patients with moderate to severe chronic plaque psoriasis: efficacy and safety results from a phase II/III randomized controlled study. J Dermatol. 2010;37(4):299-310. doi:10.1111/ j.1346-8138.2009.00748.x.

147. Mahil SK, Arkir Z, Richards G, Lewis CM, Barker JN, Smith CH. Predicting treatment response in psoriasis using serum levels of adalimumab and etanercept: a single-centre, cohort study. Br J Dermatol. 2013;169(2):306-13. doi:10.1111/bjd.12341.

148. Reich K, Nestle FO, Papp K, Ortonne JP, Evans R, Guzzo C, et al. Infliximab induction and maintenance therapy for moderate-to-severe psoriasis: a phase III, multicentre, double-blind trial. Lancet. 2005;366(9494):1367-74. doi:10.1016/S01406736(05)67566-6.
149. Mostafa NM, Nader AM, Noertersheuser P, Okun M, Awni WM. Impact of immunogenicity on pharmacokinetics, efficacy and safety of adalimumab in adult patients with moderate to severe chronic plaque psoriasis. J Eur Acad Dermatol Venereol. 2017;31(3):490-497. doi:10.1111/jdv.13884.

150. Tsai TF, Ho JC, Song M, Szapary P, Guzzo C, Shen YK, et al. Efficacy and safety of ustekinumab for the treatment of moderate-to-severe psoriasis: a phase III, randomized, placebocontrolled trial in Taiwanese and Korean patients (PEARL). J Dermatol Sci. 2011;63(3):154-63. doi:10.1016/j.jdermsci. 2011.05.005.

151. West RL, Zelinkova Z, Wolbink GJ, Kuipers EJ, Stokkers PC, van der Woude CJ. Immunogenicity negatively influences the outcome of adalimumab treatment in Crohn's disease. Aliment Pharmacol Ther. 2008;28(9):1122-6. doi:10.1111/j.1365-2036. 2008.03828.x.

152. Sandborn WJ, Schreiber S, Feagan BG, Rutgeerts P, Younes ZH, Bloomfield R, et al. Certolizumab pegol for active Crohn's disease: a placebo-controlled, randomized trial. Clin Gastroenterol Hepatol. 2011;9(8):670-8.e3. doi: 10.1016/j.cgh.2011.04.031.

153. Colombel JF, Sandborn WJ, Reinisch W, Mantzaris GJ, Kornbluth A, Rachmilewitz D, et al. Infliximab, azathioprine, or combination therapy for Crohn's disease. N Engl J Med. 2010;362(15):1383-95. doi:10.1056/NEJMoa0904492.

154. Farrell RJ, Alsahli M, Jeen YT, Falchuk KR, Peppercorn MA, Michetti P. Intravenous hydrocortisone premedication reduces antibodies to infliximab in Crohn's disease: a randomized controlled trial. Gastroenterology. 2003;124(4):917-24. doi:10. 1053/gast.2003.50145.

155. Brandse JF, Van Der Kleij D, Wolbink GJ, Rigter IM, Baars PA, Lowenberg $\mathrm{M}$, et al. The pharmacokinetics of infliximab induction therapy in patients with moderate to severe ulcerative colitis. Gastroenterology. 2014;146(5):S134. doi:10.1016/ S0016-5085(14)60474-1.

156. Bejaoui M, Charbit-Hennon F, Landman C, Sokol H, Bourrier A, Nion-Larmurier I, Cosnes $J$, et al. Predictive value of infliximab trough levels in quiescent inflammatory bowel disease under maintenance infliximab therapy. 2016. https://www. ecco-ibd.eu/index.php/publications/congress-abstract-s/abstracts2016/item/p582-predictive-value-of-infliximab-trough-levels-inquiescent-inflammatory-bowel-disease-under-maintenanceinfliximab-therapy.html. Accessed $14 \mathrm{Feb} 2017$.

157. Abe T, Takeuchi T, Miyasaka N, Hashimoto H, Kondo H, Ichikawa $\mathrm{Y}$, et al. A multicenter, double-blind, randomized, placebo controlled trial of infliximab combined with low dose methotrexate in Japanese patients with rheumatoid arthritis. J Rheumatol. 2006;33(1):37-44. http://www.jrheum.org/ content/33/1/37.long. Accessed 26 May 2017.

158. Ruperto N, Lovell DJ, Cuttica R, Woo P, Meiorin S, Wouters C, et al. Long-term efficacy and safety of infliximab plus methotrexate for the treatment of polyarticular-course juvenile rheumatoid arthritis: findings from an open-label treatment extension. Ann Rheum Dis. 2010;69(4):718-22. doi:10.1136/ ard.2009.100354.

159. Ruperto N, Lovell DJ, Cuttica R, Wilkinson N, Woo P, Espada $\mathrm{G}$, et al. A randomized, placebo-controlled trial of infliximab plus methotrexate for the treatment of polyarticular-course juvenile rheumatoid arthritis. Arthritis Rheum. 2007;56(9):3096-106. doi:10.1002/art.22838.

160. Braun J, Deodhar A, Dijkmans B, Geusens P, Sieper J, Williamson $\mathrm{P}$, et al. Efficacy and safety of infliximab in patients with ankylosing spondylitis over a two-year period. Arthritis Rheum. 2008;59(9):1270-8. doi:10.1002/art.24001.

161. van der Heijde D, Dijkmans B, Geusens P, Sieper J, DeWoody $\mathrm{K}$, Williamson $\mathrm{P}$, et al. Efficacy and safety of infliximab in patients with ankylosing spondylitis: results of a randomized, 
placebo-controlled trial (ASSERT). Arthritis Rheum. 2005;52(2):582-91. doi:10.1002/art.20852.

162. Gottlieb AB, Evans R, Li S, Dooley LT, Guzzo CA, Baker D, et al. Infliximab induction therapy for patients with severe plaque-type psoriasis: a randomized, double-blind, placebo-controlled trial. J Am Acad Dermatol. 2004;51(4):534-42. doi:10. 1016/j.jaad.2004.02.021.

163. Hanauer SB, Wagner CL, Bala M, Mayer L, Travers S, Diamond $\mathrm{RH}$, et al. Incidence and importance of antibody responses to infliximab after maintenance or episodic treatment in Crohn's disease. Clin Gastroenterol Hepatol. 2004;2(7):542-53. http:// www.cghjournal.org/article/S1542-3565(04)00238-1/fulltext. Accessed 26 May 2017.

164. Hyams J, Crandall W, Kugathasan S, Griffiths A, Olson A, Johanns $\mathbf{J}$, et al. Induction and maintenance infliximab therapy for the treatment of moderate-to-severe Crohn's disease in children. Gastroenterology. 2007;132(3):863-73. doi:10.1053/j. gastro.2006.12.003.

165. Sands BE, Anderson FH, Bernstein CN, Chey WY, Feagan BG, Fedorak RN, et al. Infliximab maintenance therapy for fistulizing Crohn's disease. N Engl J Med. 2004;350(9):876-85. doi:10. 1056/NEJMoa030815.

166. Martin Arranz MD, Martin Arranz E, Pascual-Salcedo D, De Diego C, Jaquotot M, Gomez Senent S, et al. Infliximab trough levels and antibodies: relationship with infusion reaction, immunomodulators and biological parameters. J Crohn's Colitis. 2014;8(5):S251. doi:10.1016/S0016-5085(14)60855-6.

167. Miele E, Markowitz JE, Mamula P, Baldassano RN. Human antichimeric antibody in children and young adults with inflammatory bowel disease receiving infliximab. J Pediatr Gastroenterol Nutr. 2004;38(5):502-8. http://insights.ovid.com/ pubmed?pmid=15097438. Accessed 26 May 2017.

168. Hoxha A, Calligaro A, Tonello M, Ramonda R, Carletto A, Paolazzi G, et al. The clinical relevance of early anti-adalimumab antibodies detection in rheumatoid arthritis, ankylosing spondylitis and psoriatic arthritis: a prospective multicentre study. Joint Bone Spine Rev Rhum. 2016;83(2):167-71. doi:10. 1016/j.jbspin.2015.04.020.

169. Lovell DJ, Ruperto N, Goodman S, Reiff A, Jung L, Jarosova K, et al. Adalimumab with or without methotrexate in juvenile rheumatoid arthritis. N Engl J Med. 2008;359(8):810-20. doi:10.1056/NEJMoa0706290.

170. Lovell DJ, Ruperto N, Mouy R, Paz E, Rubio-Perez N, Silva $\mathrm{CA}$, et al. Long-term safety, efficacy, and quality of life in patients with juvenile idiopathic arthritis treated with intravenous abatacept for up to seven years. Arthritis Rheumatol. 2015;67(10):2759-70. doi:10.1002/art.39234.

171. Goss SL, Klein CE, Kupper H, Burmester GR, Awni W. Adalimumab and methotrexate pharmacokinetics following combination therapy with different methotrexate doses in methotrexate and biologic-naïve rheumatoid arthritis patients: Concerto study. Arthritis Rheum. 2013;65(10 Suppl):S212. doi:10.1002/art.38216.

172. Villalba Yllan A, Plasencia C, Pascual-Salcedo D, Peiteado D, Nuño L, Bonilla G, et al. SAT0331 Effect of methotrexate on the immunogenicity of TNF inhibitors in spondyloartrhitis patients. Ann Rheum Dis. 2014;73(Suppl 2):711.3-2. doi:10. 1136/annrheumdis-2014-eular.5819.

173. Amano K, Matsubara $\mathrm{T}$, Tanaka $\mathrm{T}$, Inoue $\mathrm{H}$, Iwahashi $\mathrm{M}$, Kanamono T, et al. Long-term safety and efficacy of treatment with subcutaneous abatacept in Japanese patients with rheumatoid arthritis who are methotrexate inadequate responders. Mod Rheumatol. 2015;25(5):665-71. doi:10.3109/14397595.2015. 1012786.

174. Zhuang Y, Xu Z, Frederick B, de Vries DE, Ford JA, Keen M, et al. Golimumab pharmacokinetics after repeated subcutaneous and intravenous administrations in patients with rheumatoid arthritis and the effect of concomitant methotrexate: an openlabel, randomized study. Clin Ther. 2012;34(1):77-90. doi:10. 1016/j.clinthera.2011.11.015.

175. Emery P, Fleischmann RM, Moreland LW, Hsia EC, Strusberg I, Durez $\mathrm{P}$, et al. Golimumab, a human anti-tumor necrosis factor alpha monoclonal antibody, injected subcutaneously every four weeks in methotrexate-naive patients with active rheumatoid arthritis: twenty-four-week results of a phase III, multicenter, randomized, double-blind, placebo-controlled study of golimumab before methotrexate as first-line therapy for earlyonset rheumatoid arthritis. Arthritis Rheum. 2009;60(8):2272-83. doi:10.1002/art.24638.

176. Emery P, Fleischmann RM, Doyle MK, Strusberg I, Durez P, Nash P, et al. Golimumab, a human anti-tumor necrosis factor monoclonal antibody, injected subcutaneously every 4 weeks in patients with active rheumatoid arthritis who had never taken methotrexate: 1-year and 2-year clinical, radiologic, and physical function findings of a phase III, multicenter, randomized, double-blind, placebo-controlled study. Arthritis Care Res. 2013;65(11):1732-42. doi:10.1002/acr.22072.

177. Emery P, Fleischmann RM, Strusberg I, Durez P, Nash P, Amante E, et al. Final 5-year safety and efficacy results of a phase 3, randomized, placebo-controlled trial of golimumab in methotrexate-naïve patients with rheumatoid arthritis. Rheumatology (Oxford). 2014;53(Suppl 1):i93. doi:10.1093/ rheumatology/keu101.018.

178. Kavanaugh A, McInnes IB, Mease PJ, Krueger GG, Gladman DD, van der Heijde D, et al. Clinical efficacy, radiographic and safety findings through 2 years of golimumab treatment in patients with active psoriatic arthritis: results from a long-term extension of the randomised, placebo-controlled GO-REVEAL study. Ann Rheum Dis. 2013;72(11):1777-85. doi:10.1136/ annrheumdis-2012-202035.

179. Kavanaugh A, McInnes IB, Mease P, Krueger GG, Gladman D, van der Heijde $\mathrm{D}$, et al. Clinical efficacy, radiographic and safety findings through 5 years of subcutaneous golimumab treatment in patients with active psoriatic arthritis: results from a long-term extension of a randomised, placebo-controlled trial (the GO-REVEAL study). Ann Rheum Dis. 2014;73(9):1689-94. doi:10.1136/annrheumdis-2013-204902.

180. Inman RD, Davis JC Jr, Heijde D, Diekman L, Sieper J, Kim SI, et al. Efficacy and safety of golimumab in patients with ankylosing spondylitis: results of a randomized, double-blind, placebo-controlled, phase III trial. Arthritis Rheum. 2008;58(11):3402-12. doi:10.1002/art.23969.

181. Sandborn WJ, Feagan BG, Marano C, Zhang H, Strauss R, Johanns J, et al. Subcutaneous golimumab maintains clinical response in patients with moderate-to-severe ulcerative colitis. Gastroenterology. 2014;146(1):96-109.e1. doi:10.1053/j.gastro. 2013.06.010.

182. Sandborn WJ, Feagan BG, Marano C, Zhang H, Strauss R, Johanns J, et al. Subcutaneous golimumab induces clinical response and remission in patients with moderate-to-severe ulcerative colitis. Gastroenterology. 2014;146(1):85-95. doi: 10. 1053/j.gastro.2013.05.048.

183. Maini RN, Breedveld FC, Kalden JR, Smolen JS, Davis D, Macfarlane JD, et al. Therapeutic efficacy of multiple intravenous infusions of anti-tumor necrosis factor alpha monoclonal antibody combined with low-dose weekly methotrexate in rheumatoid arthritis. Arthritis Rheum. 1998;41(9):1552-63. doi:10.1002/1529-0131(199809)41:9<1552::AID-ART5>3.0. $\mathrm{CO} ; 2-\mathrm{W}$.

184. Gainaru C, Diana M, Iliuta M, Luca G, Apetrei N, Constantinescu $C$, et al. Infliximab vs etanercept: the importance of immunogenicity and serum drug monitoring in clinical practice. 
Ann Rheum Dis. 2014;73:245. doi:10.1136/annrheumdis-2014eular.4828.

185. Feagan BG, McDonald JW, Panaccione R, Enns RA, Bernstein $\mathrm{CN}$, Ponich TP, et al. Methotrexate in combination with infliximab is no more effective than infliximab alone in patients with Crohn's disease. Gastroenterology. 2014;146(3):681-8.e1. doi:10.1053/j.gastro.2013.11.024.

186. Baert F, Noman M, Vermeire S, Van Assche G, D'Haens G, Carbonez A, et al. Influence of immunogenicity on the longterm efficacy of infliximab in Crohn's disease. N Engl J Med. 2003;348(7):601-8. doi:10.1056/NEJMoa020888.

187. Bortlik M, Duricova D, Malickova K, Machkova N, Bouzkova E, Hrdlicka L, et al. Infliximab trough levels may predict sustained response to infliximab in patients with Crohn's disease. J Crohn's Colitis. 2013;7(9):736-43. doi:10.1016/j.crohns.2012. 10.019 .

188. Bar-yoseph H, Chowers Y, Ben-Horin S, Waterman M. Infliximab is more immunogenic and reaches lower trough levels in ulcerative colitis patients compared to Crohn's disease patients. Gastroenterology. 2013;144(5 Suppl 1):S-780-S. doi:10.1016/ S0016-5085(13)62883-8.

189. Hayes MJ, Stein AC, Sakuraba A. Comparison of efficacy, pharmacokinetics, and immunogenicity between infliximab mono- versus combination therapy in ulcerative colitis. J Gastroenterol Hepatol. 2014;29(6):1177-85. doi:10.1111/jgh/12517.

190. Inciarte-Mundo J, Hernández MV, Cabrera S, Ruiz-Esquide V, Ramirez J, Cañete JD, et al. Immunogenicity induced by tumor necrosis factor antagonists in chronic inflammatory arthropathies: retrospective study in clinical practice conditions. Arthritis Rheum. 2013;65(10 Suppl):S613. doi:10.1002/art. 38216.

191. Marits P, Landucci L, Sundin U, Davidsdottir L, Nilsson J, Befrits R, et al. Trough s-infliximab and antibodies towards infliximab in a cohort of 79 IBD patients with maintenance infliximab treatment. J Crohn's Colitis. 2014;8(8):881-9. doi:10. 1016/j.crohns.2014.01.009.

192. Steenholdt C, Al-khalaf M, Brynskov J, Bendtzen K, Thomsen OO, Ainsworth MA. Clinical implications of variations in antiinfliximab antibody levels in patients with inflammatory bowel disease. Inflamm Bowel Dis. 2012;18(12):2209-17. doi:10. 1002/ibd.22910.

193. van Schaik T, Maljaars JP, Roopram RK, Verwey MH, Ipenburg $\mathrm{N}$, Hardwick JC, et al. Influence of combination therapy with immune modulators on anti-TNF trough levels and antibodies in patients with IBD. Inflamm Bowel Dis. 2014;20(12):2292-8. doi:10.1097/MIB.0000000000000208.

194. Ungar B, Haj-Natour O, Kopylov U, Yavzori M, Fudim E, Picard $\mathrm{O}$, et al. Ashkenazi Jewish origin protects against formation of antibodies to infliximab and therapy failure. Medicine (Baltimore). 2015;94(18):e673. doi:10.1097/MD. 0000000000000673.

195. Afif W, Loftus EV Jr, Faubion WA, Kane SV, Bruining DH, Hanson KA, et al. Clinical utility of measuring infliximab and human anti-chimeric antibody concentrations in patients with inflammatory bowel disease. Am J Gastroenterol. 2010;105(5):1133-9. doi:10.1038/ajg.2010.9.

196. Keystone EC, Kavanaugh AF, Sharp JT, Tannenbaum H, Hua Y, Teoh LS, et al. Radiographic, clinical, and functional outcomes of treatment with adalimumab (a human anti-tumor necrosis factor monoclonal antibody) in patients with active rheumatoid arthritis receiving concomitant methotrexate therapy: a randomized, placebo-controlled, 52-week trial. Arthritis Rheum. 2004;50(5):1400-11. doi:10.1002/art.20217.
197. Weinblatt ME, Keystone EC, Furst DE, Moreland LW, Weisman $\mathrm{MH}$, Birbara CA, et al. Adalimumab, a fully human antitumor necrosis factor alpha monoclonal antibody, for the treatment of rheumatoid arthritis in patients taking concomitant methotrexate: the ARMADA trial. Arthritis Rheum. 2003;48(1):35-45. doi:10.1002/art.10697.

198. Ben-Bassat O, Hauenstein S, Iacono A, Irwin SP, Singh S, Greenberg GR. Serum adalimumab and immunogenicity in IBD patients after $80 \mathrm{mg}$ biweekly maintenance therapy. Gastroenterology. 2013;144(5):S771. doi:10.1016/S0016-5085(13) 62851-6.

199. Hyams J, Ruemmele F, Colletti R, Kierkus J, Rosh J, Eichner S, et al. Impact of concomitant immunosuppressant use on adalimumab efficacy in children with moderately to severely active Crohn's disease: results from IMAgINE 1. J Crohn's Colitis. 2014;8(Suppl 1):S257-8. doi:10.1016/S1873-9946(14)60578-X.

200. Magdelaine-Beuzelin C, Vermeire S, Goodall M, Baert F, Noman M, Assche GV, et al. IgG1 heavy chain-coding gene polymorphism (G1 m allotypes) and development of antibodiesto-infliximab. Pharmacogenet Genomics. 2009;19(5):383-7. doi:10.1097/FPC.0b013e32832a06bf.

201. Emery P, Fleischmann R, Filipowicz-Sosnowska A, Schechtman J, Szczepanski L, Kavanaugh A, et al. The efficacy and safety of rituximab in patients with active rheumatoid arthritis despite methotrexate treatment: results of a phase IIB randomized, double-blind, placebo-controlled, dose-ranging trial. Arthritis Rheum. 2006;54(5):1390-400. doi:10.1002/art.21778.

202. Jani M, Barton A, Warren RB, Griffiths CE, Chinoy H. The role of DMARDs in reducing the immunogenicity of TNF inhibitors in chronic inflammatory diseases. Rheumatology (Oxford). 2014;53(2):213-22. doi:10.1093/rheumatology/ket260.

203. Roblin X, Rinaudo M, Del Tedesco E, Phelip JM, Genin C, Peyrin-Biroulet L, et al. Development of an algorithm incorporating pharmacokinetics of adalimumab in inflammatory bowel diseases. Am J Gastroenterol. 2014;109(8):1250-6. doi:10.1038/ajg.2014.146.

204. van der Bijl AE, Breedveld FC, Antoni CE, Kalden JR, Kary S, Burmester GR, et al. An open-label pilot study of the effectiveness of adalimumab in patients with rheumatoid arthritis and previous infliximab treatment: relationship to reasons for failure and anti-infliximab antibody status. Clin Rheumatol. 2008;27:1021-8. doi:10.1007/s10067-008-0866-4.

205. Frederiksen MT, Ainsworth MA, Brynskov J, Thomsen OO, Bendtzen K, Steenholdt C. Antibodies against infliximab are associated with de novo development of antibodies to adalimumab and therapeutic failure in infliximab-to-adalimumab switchers with IBD. Inflamm Bowel Dis. 2014;20(10):1714-21. doi:10.1097/mib.0000000000000138.

206. Moss AC. Optimizing the use of biological therapy in patients with inflammatory bowel disease. Gastroenterol Rep (Oxf). 2015;3(1):63-8. doi:10.1093/gastro/gou087.

207. Vaughn BP, Sandborn WJ, Cheifetz AS. Biologic concentration testing in inflammatory bowel disease. Inflamm Bowel Dis. 2015;21(6):1435-42. doi:10.1097/MIB.0000000000000312.

208. Christen U, Thuerkauf R, Stevens R, Lesslauer W. Immune response to a recombinant human TNFR55-IgG1 fusion protein: auto-antibodies in rheumatoid arthritis (RA) and multiple sclerosis (MS) patients have neither neutralizing nor agonist activities. Human Immunol. 1999;60(9):774-90. http://www.sciencedirect. com/science/article/pii/S0198885999000683. Accessed 26 May 2017. 